6. He:

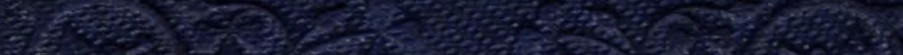

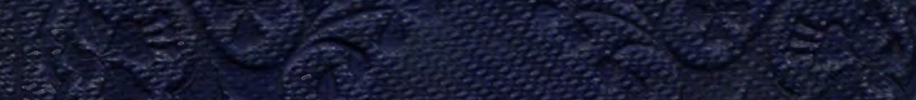

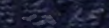

$\frac{2}{2} x^{2}$

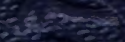

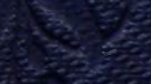

$$
\text { की }
$$

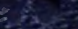

s.

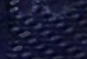

:
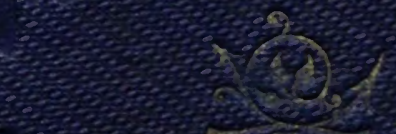

起

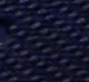

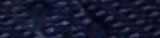

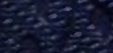

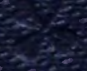

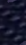

$(2), 0$ )

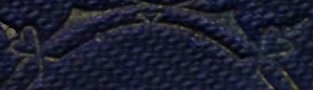

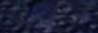

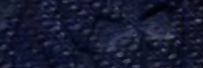

2013

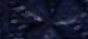

年,

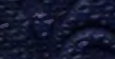

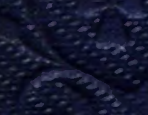

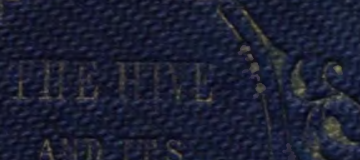

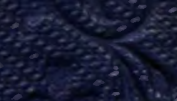

1)

isterses
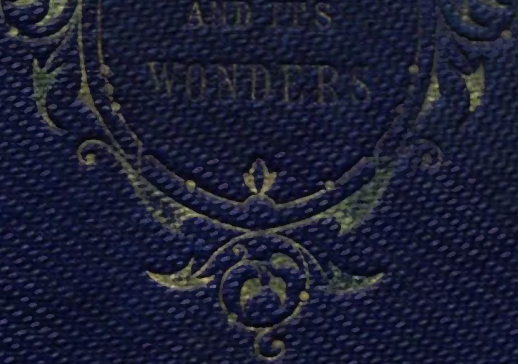

torses

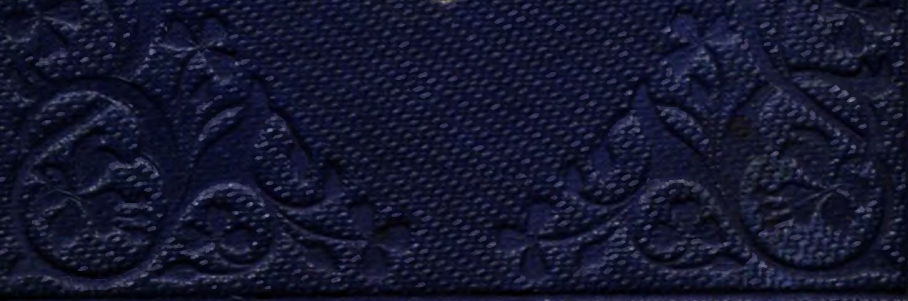


ffrancies Gyren.

ar lift qromeli.,

Affect hottion 


$$
\begin{aligned}
& \text { से है की } \\
& j^{2} \times b^{2}
\end{aligned}
$$


Square $16 \mathrm{mo}$, cloth, price ls. 6 d., gilt edges,

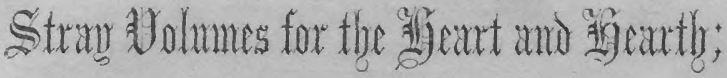 of.}

apingt and apolo for Houthrinl circles.

1. EDWARD AND MARY: A Story Illustrative of the Nature and Effects of True Love to God.

2. THE NEW SCHOLAR; OR, THE FEAR OF GOD AND THE Fear of Man, How they Differ and Which to Choose.

3. ROBERT DAWSON; OR, THE Brave SPIRIT.

4. THE VALLEY OF DECISION; oR, Divine Teachings in a Boarding School. A True Narrative. By Mrs H. C. KNIGHT.

5. JANE MORRIS; AND OTHER NARRATIVES FOR BEGINNERS IN THE SPIRITUAL LiFs. By the Author of "The Valley of Decision."

(Series to be Continued.)

"The delightful title of this series is fully borne out by the loving, sensible, and domestic spirit in which the tales are written. . . A set of as pretty and delightful little souvenirbooks for the young as any happy Christmas ever saw."-Edinburgh Advertiser.

"It is scarcely possible to convey a full idea of the amount of practical good sense and stern truth which these admirable treatises develop. They must be read to be fully appreciated; and fully appreciated they will doubtless be whenever they gain a circulation, which, we trust, will be as extensive as their merits." - Bellis Weekly Messenger.

"They blend valuable instruction with fascinating narrative." - North British Daily Mail. 


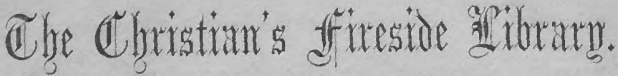

Fep. 8vo, in Sets of 4 Vals., 6s.; or Single Vols., Cloth, Lettered, each, 2s. 6 d.

First Year's Issue-1850-1851.

GLEANINGS AMONG THE MOUNTAINS; OR, TRADItions of the Covenanters. By the Rev. R. Simpson. THE DIVINE INSPIRATION OF THE SCRIPTURES By Dr Gaussen of Geneva. A New Translation.

THE MISSIONARY IN THE WILDERNESS; being the Life of David Brainerd. By President Edwards. With

Introductory Essay by the Rev. Horatius Bonar, Kelso. COMFORT IN AFFLICTION: A Series of Meditations. By

James Buchanan, D.D., Edinburgh.

Second Year's Issue-1851-1852.

THE PROVINCIAL LETTERS OF BLAISE PASCAL. A

New Translation, with Historical Introduction and Notes.

By Thomas M'Crie, D.D.

THE EVIDENCES OF CHRISTIANITY. By CharLes P. M.ILVAINE, D.D., Ohio.

A HANDBOOK OF POPERY. By JAMES BEgG, D.D. MEMOIR AND REMAINS OF THE REV. EDWARD PAYSON, D.D.

Third Xen*'s Issue-1852-1858 [In preparation.]

THE BIBLE IN THE FAMILY; oR, HINTS oN DOMESTIC Happiness. Together with THOUGHTS ON FAMILY WORSHIP. In one Volume.

A MANUAL OF BIBLICAL ANTIQUTTIES. THE LIFE OF JOHN NEWTON. By the Rev, R. CEcIL. GREAT SERNONS OF GREAT PREACHERS.

Johnstone \& Hunter, 15 Princes Street, Edinburgh;

R. Theobald, 26 Patemoster Row, London. 


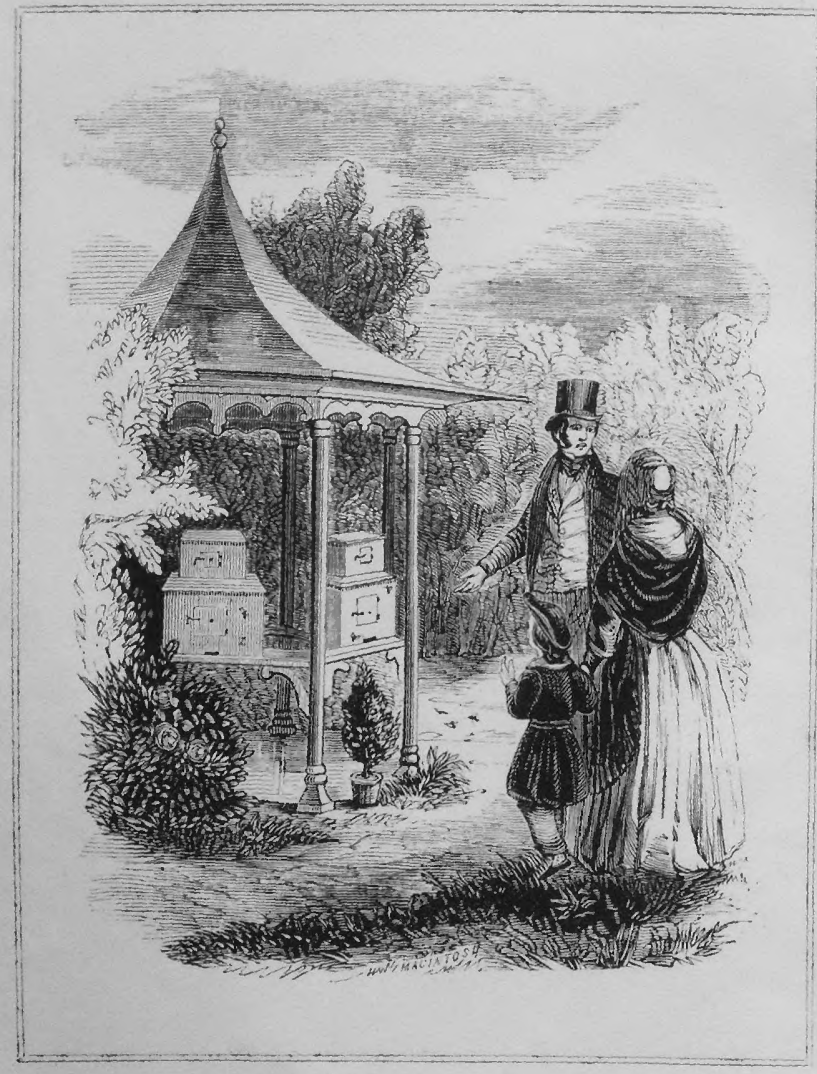




\section{THE HIVE}

\section{AND ITS WONDERS.}

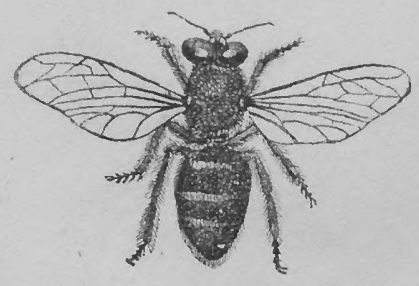

EDINBURGH:

JOHNSTONE AND HUNTER. 


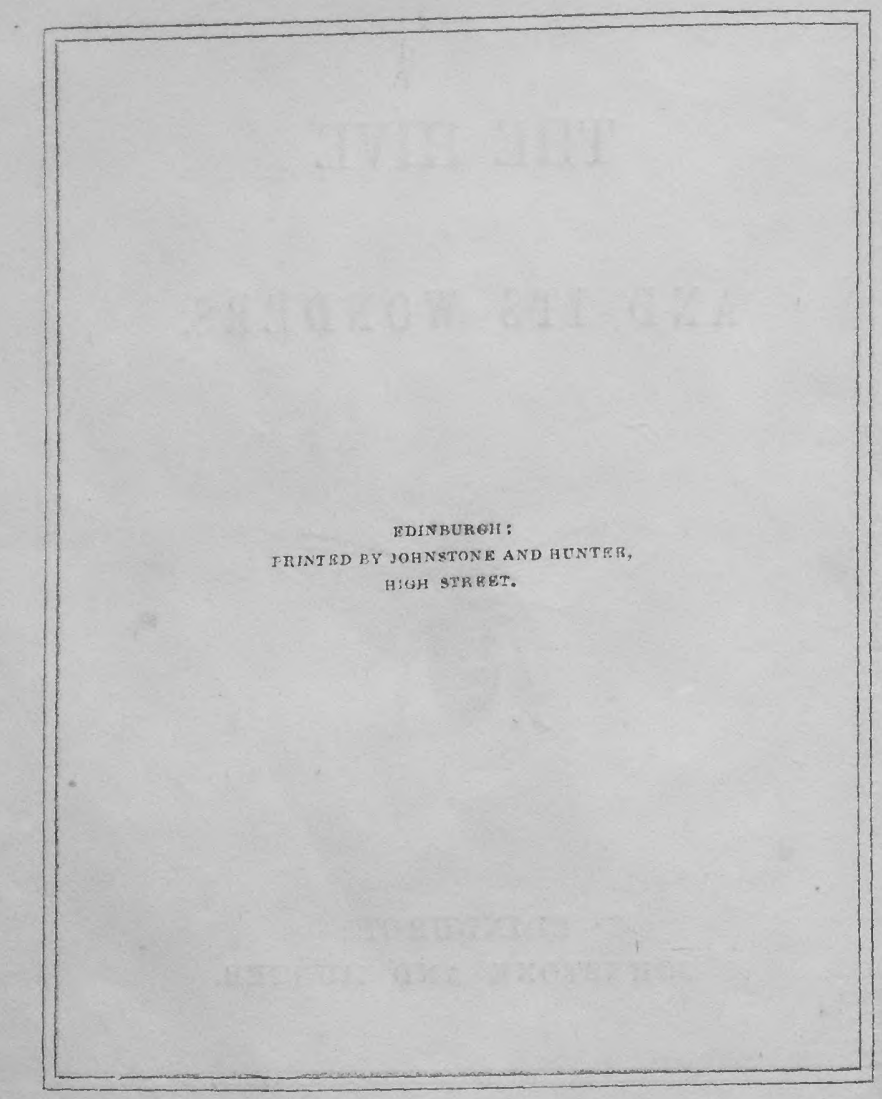




\section{CONTENTS.}

\section{CHAPTER I.}

The Bee-A well-known Insect .
CHAPTER II.

The Queen, or Mother of the Hire-The Drones-The Workers

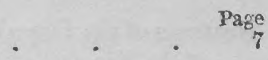


CHAPTER VII.

The Queen-Care of the Young .

\section{CHAPTER VIII.}

Swarming of the Bees
CHAPTER IX.

Neatness of the Bee-Ventilation of the Hive-Enemies of the Bee -

Sting of the Bee-Anger of Bees-Attack of Missionaries by Wild-Bees .

CHAPTER XI.

Age-Flight of the Bee-Bee-Hunter-I'ransportation of Hives

\section{CHAPTER XII.}

Wax-Honey

CHAPTER XIII.

Instinct of the Bee 


\section{THE HIVE AND ITS TONDERS.}

\section{CHAPTER I.}

THE BEE-A WELL-KKNOWN INSECT.

THe honey-bee is known in almost all parts of the world. Far and wide the pleasant hum of its busy wings has been heard; and the sweet flowers have bent their heads beneath the weight of its light foot. steps, as it gathered its honeyed store.

It is one of the most remarkable of all the insects, and perhaps to us it is the most interesting of all, on account of its wonderful knowledge and skill, its industry, and the benefits which its labours confer upon us, in the production, for our use, of its honey and wax. 
This little insect has long been thought by learned men to be worthy of much attention. We read of one person, who, centuries ago, gave up many years of his life to the study of the habits and customs of the bee. Another is said to have spent his days in the forests where the wild bees made their homes, in order to observe all their proceedings with the greatest carc. Each of these persons wrote down what he had learned respecting the bee.

A very large number of books have been written about the honey-bee. It has been noticed that no nation of the earth, however important, has had its history so often written as this curious insect.

The bee was well known in ancient times to the inhabitants of the land of Palestine. Honey and the honey-comb are frequently mentioned in the Scriptures. Judea is many times called a "land flowing with milk and honey;" and though this no doubt refers to the richness of the country in general, yet the honey and milk spoken of must have been found in plentiful abundance, and highly valued by the people. The wild bees were especially numerous; 
they formed their combs in any convenient place that offered, in the trees of the forests, or holes of the rocks. In these places were often found the richest honeycombs. Thus the Israelites were sometimes fed "with honey out of the rock." Honey was used at their meals, with butter or milk, as a refreshing and delicious article of food. The honey-comb, cut in slices, with bowls of milk and cream, and boiled rice, is served up to strangers and visitors at the present time by the Arabs.

The great number of bees in Palestine is still noticed by travellers; and they were probably far more numerous formerly than they are now, when the land is so much less cultivated. TVe are told that, in some parts of India, the forests swarm with bees; and large combs are seen, as you pass along, hanging from the trees, full of honey. Probably this was the case also in Palestine.

The bees appear to be very common throughout every part of Africa, and the ressels trading along the coasts are often partly loaded with a cargo of beeswax. On the western coast, near the river 


\section{TUE HIVE AND ITS WONDERS.}

Ganıbia, the natives formerly paid much attention to the care of the bees. They had hives, made of reeds and sedge, shaped like baskets, and hung on the outer boughs of the trees. The bees took possession of these hives, and built their combs in them. In some places, they were hung so thickly, that they looked, at a short distance, like large fruit on the branches. There, too, the bees make a great deal of honey in the hollow trees.

In South Africa, a party of Hottentots, who were in company with some travellers, once took several pounds of good honey from a hole, which had been the dwelling of the little weasel. In the same country, the bees are often found occupying the nests or hills, built by the white ants, then deserted, and left empty by them. The bees, in their wild state, seem not very particular in choosing a place for their home; or, perhaps, if they cannot find such a one as they like, they take the best they can get, and are satisfied with it.

It is a singular fact, that in Southern Africa, a most remarkable little bird is sometimes seen, called 
the honey-guide, whose office it is to point out to the natives and others the nests of the wild-bees, where their honey is stored. This wonderful bird is quite small in size, and of a light grey colour. It seems never alarmed at the presence of man, but rather to be pleased to make his acquaintance. When wishing to attract attention, it perches on a branch beside the traveller, clıattering and twiţtering in a peculiar way; then flits from tree to tree, continuing all the time its most expressive note of invitation. This call is well understood by the natives, and a person invited by the honey-guide seldom refuses to follow. When the bird has succeeded in gaining attention, it flies lightly forward, in the direction of the bees' nest; rising a little, now and then, in its flight, or alighting and looking back, as if to ascertain if it is still pursued. When, at length, it arrives at the hollow tree, or the deserted white ants'-hill, which contains the honey, it hovers over it for a moment, pointing to it with its bill ; then takes its place on the branch of a tree near, and awaits its portion of the spoil. A share of the honey is always left for the bird, as it would be con- 
sidered wrong to rob it of what it has so truly earned, or in any way to hurt so useful a creature.

When the honey is taken, which is done by burning grass at the entrance of their dwelling and making the bees stupid with the smoke, the honey-bird will often lead to a second, or even to a third nest. It is common for the person following it to whistle while on the way; and the natives are so fond of the honey, that they will leave their preparation for the most exciting pleasures of the chase, if they hear the call of the honey-guide, and see its little form flitting before them. This curious bird, perhaps, finds itself unable to make war with the bees, or to get at the honey without more powerful help, and is thus led to invite the assistance of man. The wild-bee of Southern Africa corresponds in appearance with our own domestic garden-bee.

Though now common in America, the honey-bee is thought not to be a native of that continent, but to have been introduced by some of the early emigrants who went to make their home upon its shores. In many instances they left the protection of man, and 
spread into the interior of the country, a little before the white settlers took possession of it; and it is said that, as the bee advances, the Indian and the buffalo retire before them. It is probable that not very many years have passed away since the hum of the bee was unheard in the vast regions on the western side of the Alleghany mountains, now so thickly inhabited, and where so much honey is produced. No wonder, then, that the poor Indian should call them the "white man's fly;" and when he saw a swarm of bees make its appearance, in its flight over some wide prairie of the west, should say, "The white man is coming," and feel that the beautiful country, then all his own, would soon be no longer a home for him and his race.

The Creator, by whose wisdom this little insect was first made, gave it also the skill to contrive and the power to construct its comb, and carry on its labours, whether in holes of the rocks or trees, or in the convenient hive. He formed its body, so curious in all its parts, and each so exactly adapted to the use for which it was intended. The largest and most powerful animals in the world, the huge elephant, the patient 
camel, or the noble horse, are not more remarkable, as the work of the Creator, than the little bee. When we look upon these, and all his works, we feel that, though they speak not in words, they yet seem silently to declare to every one, "God made us: He is almighty in goodness, in wisdom, and in power!"

"O Thou, to whom all creatures bow

Within this earthly frame,

Through all the world, how great art Thou?

How glorious is Thy name !" 


\section{CHAPTER II.}

THE QUEEN, OR MOTHER OF THE HIVE-THE DRONESTIIE WORKERS.

Trie honey-bee never lives alone, but always in a family or society, with many of its own species. None but the wild-bees are obliged to take care of themselves, and provide a place for their own dwelling; for very convenient hives are built for the domestic bees, where they find shelter and a comfortable home. These hives, whether made of straw, boards, or glass, are merely the necessary outside covering; the city of the bee is built within the live. Here we must look for her cunning work, - the streets, the houses, the palaces, which she contrives; and here are to be found her numerous family.

The family or society in each hive is always composed of three classes of bees-the queen, the drones, 
and the workers. The queen is the mother, as well as

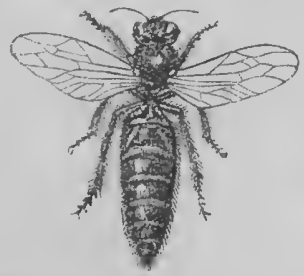

The Queen of the Five.

the sovereign of the hive. In shape, she is more slender than the other bees. Her body is much longer and tapers gradually to a point. Her legs are longer than theirs, but her wings are much shorter, reaching but little more than half the length of her body. She is armed with a bent or curved sting, but she does not often use it, except in her wars with other queens. The colour of her back is dark brown, but the under part of her body is lighter, more of a bright orange colour.

The queen-bee does no work, and she is treated with the greatest respect and attention by all the other bees. 
Although the hive is dark, they always know their queen. If she is killed, or by any accident they are deprived of her, they appear to be entirely without comfort. They leave their work, and seem to lose all interest in their labours for a time.

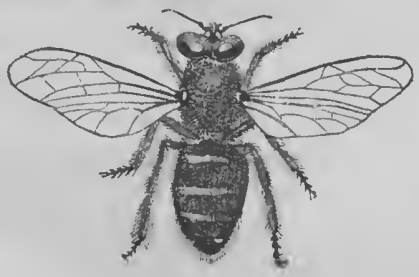

The Drone, or Male Bee.

The drones are the largest of the bee family; they are nearly twice as large as the workers. Their bodies are thick and clumsy, and covered with hairs much more closely than the other bees. The head of the drone is large; so are its eyes; and its wings are very large, and quite as long as its body. The drones have no sting; of course they may be handled without any danger. They make a loud buzzing noise 
in flying. It is not a new thing to find that those who make the most noise are not always the most useful.

The same number of drones is not found in every hive, and it does not seem to depend on the number of workers in the hive. The proportion is usually supposed to be about one to twenty; that is, a family consisting of a queen and ten thousand workers would contain five or six hundred drones. This proportion, however, is not correct with respect to every swarm.

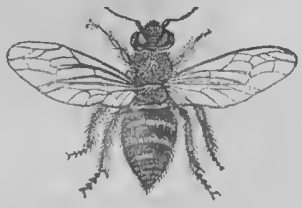

The Worker-Bee.

The workers are the smallest bees of the hive. They are the labourers, the industrious part of the family. They are busy bees, indeed, doing the work for all the rest. They collect the honey and pollen, they build 
the waxen cells, take care of the young, and defend the hive, so far as they are able, from enemies of every kind.

The worker-bee has a long, slender trunk or proboscis, with which it gathers the honey from the flowers; and its hinder legs are furnished with brushes and baskets, to collect the pollen, and carry it safely to the hive. No other bee has these baskets but the worker-bee. The sting of the worker is not curred like that of the queen. It is so sharp and strong, that it will pierce through a thick leather glove. It consists of three parts-a sheath and two very small darts. Each of these darts is edged with little crooked points, which cannot be seen without a magnifying glass; these sticking in the flesh make the wound more painful. But the wound would scarcely be felt, if it were not for the poison which the bee puts into it; first, the sharp-pointed sheath enters the flesh, and next the little darts, through which the poison quickly passes. This poison is contained within the body of the insect for this very purpose: it is made from the honey which she eats, and is so venomous, that the 
smallest quantity is sufficient to cause great pain. The sting generally remains fast in the flesh, is drawn out of the body of the insect, and causes its death. The poor bee, then, is angry when she stings, but it is to her own hurt; she never stings again. A hasty temper is sure to cause sorrow.

Every bee has six legs and four wings. Its body is composed of three distinct parts, and, except the head, is divided into rings or sections. The wings are attached to the chest or middle part of the body of the bee. If you will examine a pair of the bee's wings, you will find them dry and transparent, so that you may see through them. They are not covered over with little dust-like scales as the rings of the butterfiy are, but are formed of two thin membranes, laid one on the other, and joined together by horny lines, which are really tubes for the passage of the air. Their eyes are on the upper surface of the head; and every bee has a pair of long horns, called antennæ, rising from each side of the head. These antennæ, or feelers, are probably the seat of the sense of touch in the bee, and perhaps of smell; but this we 
do not know. They appear to distinguish a stranger bee at once, by touching it with them.

The office of the queen-bee is to lay eggs in the cells prepared by the workers for that purpose. These cells differ in size or shape, as they are intended to contain eggs that are to become drones, or those that are to become workers. The royal cell, or that of the queen, is quite different from either. It is something like a pear in shape; the upper, or largest part fastened to the edges or sides of the comb; the smaller

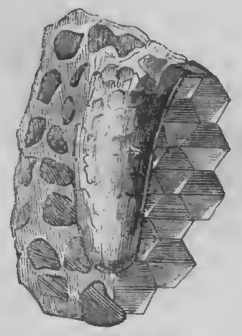

Royai Cell.

end, where the mouth or entrance to the cell is placed, always hanging downwards. 
The eggs are of a bluish-white colour, rather oval in shape, and about the size of those which are laid by the butterfly upon the cabbage-leaves. The queen begins to lay the eggs early in the spring, a single one only in each cell. The number laid is increased as the weather becomes warmer. The eggs remain for full three days, and then a little worm is hatched in the bottom of each cell. These worms, or larva, as they are called, open wide their mouths for food, and their wants are attended to by a part of the workcrs (called nurse-becs), who feed them with a mixture of bee-bread, honey, and water, which they make into a kind of jelly. When the worm is nearly grown, its food is put directly into its mouth by the nurse-bees, very much as the old birds feed the young. This is done for five or six days. They then make a covering for each cell, and seal it over. This lid or covering is very different from that which the bees place over the honey-cells. The honey-lid is of the purest wax; but the lid which closes the cells containing the young is made of wax and pollen, mingled together, and dark in colour. It is not flat, like the first, but 
its shape is peculiar, resembling that of a saucer turned over, and thus, being raised in the centre, more space is given to the young creature within to move and breathe. As soon as the little worm is sealed up, it begins to wrap round itself a cocoon or silken shroud, much like that of the silkworm. This expands, fills the cell, and makes it smooth and soft.

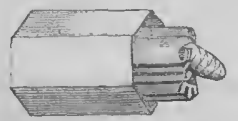

Caterpillar of the Bee, with its Cocoon of silk.

While hidden in this covering, it is called a chrysalis; and this is the second change through which it passes. Here the little creature rests, seeming to have no life or powers of any kind, until the appointed time for it to break from the confinement of its shroud and of its cell, and to come forth, entering, as it were, upon a new life. It is now a perfect bee; and, from its place of rest, as a poor, lowly worm, it sails into the air, and enters upon new scenes and new employments.

The time required for these changes is different 
with each class of bees. The first eggs laid by the queen, early in the season, are those of the workers; at a later period, she begins also to deposit those which produce drones. At the same time with the latter, the workers having prepared the royal cells, sometimes fifteen or twenty in number, a single egg is placed in each of these by the queen, always at intervals of at least a day. The workers pass through all their changes, from the laying of the egg, and come out from the cell in twenty days; the queens in sixteen; the drones, not for twenty-four days.

The singular change through which each little bee passes, - the worm wrapped in its shroud, shut up from the air and light, in a torpid, death-like state; then bursting its enclosure, and rising upward, on its light wings, a new and beautiful creature, - these things so remarkable, bring to our minds thoughts of great interest to ourselves. We must each lie down in the lonely grave, our bodies must crumble into dust, and we, perhaps, be forgotten. But is this the end of our being? Oh, no: the day will come when all the dead shall hear the voice of the Son of Man, 
and shall come forth! The earth and sea shall give up their dead! Then death shall be swallowed up of life. The children of God shall be clothed in the beautiful and spotless robe of Christ's righteousness, and the day of their happiness and glory shall begin.

"The stars shall dim their brightness;

And as a parched scroll,

The earth shall fade,-yet still shall live

The undying human soul!" 


\section{CHAPTER III.}

THE YOUNG BEE-DRONES- IONEY.

"Look now abroad. All creatures see, How they are fill'd with life and glee!

The little bee among the flowers

Hath labour'd since the morning hours,

Making the pleasant air astir,

And, with its murmurings, pleasanter."

The little bee seems to enjoy the life which the Creator has given it. As soon as it can use its wings, it appears to know perfectly what its duties and occupations are to be for the rest of its life.

For a day or two after it emerges from its cell, the young bee is pale in colour, feeble, and entirely unable to fly. But, gradually, it gains strength, walks about upon the comb, seeks for the door of the hive, and prepares to go abroad and to be uesful. 
How different is this from the infancy of man! So helpless and ignorant, needing to be cherished and protected for weeks, months, and years! The infant opens its eyes upon the light and looks around, but it knows nothing. It could not guard itself from a single danger. It would soon close its eyes again upon this world for ever, but for the fond care and watchfulness of its kind friends. What love and tenderness is shown to the little babe to preserve its feeble life!

Not so with the young bee. It needs no tender care! It requires no other bee to lead it forth or point out its task, to teach it in what direction to fly or what flowers it should visit. All this it fully uuderstands. It is ready and prepared in every respect for its daily work. From that hour, the worker-bee is never idle. It seems never to tire, but is constantly busy and happy. It is always the idle people who are the unhappy people; and they are the drones of society who do not love to work.

The drones of the bee-hive never labour; and they enjoy a very short life. They are born, and die; and this is nearly all of their history. Their name is 
given them from their lazy habits, and because they live in luxury on the labours of others. When they are only two or three months old, the bees destroy them all, killing them usually with their stings, and carrying them out of the hive. Their dead bodies may often be seen, toward the close of summer, scattered thickly around the door of their divelling.

This may seem to us very cruel. But the bees always act in this manner; when they have no further usc for their weaker companions, those who are strong and powerful destroy them. The unfortunate bee who has lost a leg or a wing, and is thus so disabled that it cannot labour, is not suffered to live and take up the room of the hive, dependent on others for its support. Many bees are born imperfect, or maimed, in this way, and they are all dragged out and killed. In this, the bees appear to us quite savage and ferocious. But their instinct teaches them thus to rid the hive of a useless and burdensome part of their family, which they could never continue to maintain; and we must not think hardly of them on this account. 
We know that, in heathen countries, the sick, the deformed, and the aged, have often been deserted by their friends, even by their own children, and left alone to die. Why is it that we differ from them? Only that we have the Bible to teach us, that the light of the blessed gospel shines around us! We understand that it is our duty to cherish and take care of the infirm, and all those who are unable to take care of themselves; and with what pleasure do we wait upon them, and try to relieve all their wants! We know, too, that they and we, unlike the poor, perishing insect, have a spiritual and immortal nature, that can never cease to live!

The active working-bee has plenty to do. It is not a selfish creature, seeking its own enjoyment, and to gratify its taste before that of its companions. It is content to labour for the good of the society to which it belongs. Full of life and vigour, it takes its first flight, visits with the other bees the sweetest flowers, loads itself with a rich burden, and returns joyfully to the hive to deposit its treasures.

But, how is the little creature furnished for its 
work? One of the principai things she has to do is to collect the pure fluid, called the nectar of flowers. This affords the bee its chief store of honey. If you examine the long tube of the honeysuckle, you will find it contains this sweet food of the bee. But the bee can obtain it, robbing the flower of its sweets, for the use of the hive, without destroying, or injuring in the least, the bright blossom where it was gathered.

She has a most remarkable tongue, given her for this very purpose. It is long and quite flexible. It is not a tube through which the honey passes, nor a kind of pump to draw it up, but a real tongue, to lick or lap up the boney and pass it along, on its upper surface, into the mouth. She keeps it folded up, or unfolds it very rapidly, at her pleasure; she pushes it forward, either in a curve or straight line, and darts it into every part of a flower where honey is to be found.

"Thus daily her task she pursues,

And pilfers with so much address,

That none of their odour they lose,

Nor charm by their beauty the less. 
"The worm, more expensively fed, The pride of the garden devours; And birds perk the seed from the bed, Still less to be spared than the flowers.

"But she with such delicate touch, Her pillage so fits for her use, That a chemist, in vain, with his skill, Would labour the like to produce."

Look at the active little insect, as she alights upon an open flower! The blossom vibrates upon its slender stem, as she touches its soft leaves. The hum of her wings ceases, and her work begins. In an instant she unfolds her tongue, she extends it to its full length, then shortens it again, and passes it over both the upper and under surface of the beautiful petals, that she may wipe off from them all their nectar. All this time, she keeps herself in constant motion. The nectar thus lapped out of the nectary of the flower, is conveyed to her honey-bag or crop, until this small deposit is filled with the pure honey. When she has completed her lading, she returns to the hive to dispose of it. The curious little bag in 
which she carries her treasure is entirely distinct from the stomach of the bee. It is surrounded by muscles adapted to the purpose, with which she compresses or contracts it at her pleasure, forcing the rich liquid from the bag through her mouth.

If the cell she selects already contains some honey, she pierces a hole in the crust formed on its surface, drops from her mouth the honey she has just brought home, and closes up the opening in the crust, leaving it quite covered. A single cell will hold the contents of many honey-bags. The honey intended for daily use is easy of access, but that which is stored away for a bad season, or laid up for winter and early spring, is placed more out of the way, and each cell is carefully sealed with a waxen cover.

The bees do not gather this sweet nectar from every flower. Some of the most lovely of the ornaments of the garden, the roses, pinks, and carnations, afford them little or no supply; while from the more humble, fragrant plants, the borage, sage, and rosemary, they collect the finest and most delicate honey. The bright pink blossom of the oleander yields a 
poisonous sweet, which destroys thousands of imprudent flies; but the bees, more wise, or more cautious, pass them by untouched. But when the fresh flowers of the linden-tree are blooming, when the apple-trees are loaded with their fragrant blossoms, or when the air is perfumed with the richness of the white clover, then they are active and busy indeed!

Of the sweet mignonette and lemon thyme the bees are very fond. But they much prefer to have every thing on a large scale, and whole fields of clover and of buckwheat attract them more than single plants, even of the finest flowers. Their practice is, when collecting honey, to adhere to the same species of flower on which they first alight. They do not fly from the linden to the apple-tree, and then to the clover, and thus mingle the nectar of the different plants; but from each single excursion, they return to the hive with that which they have procured from one description of flowers.

Perhaps no other plant can compare with the white clover in value for the use of the bees; it is in bloom almost all the summer, and affords the purest and most 
delicious honey. The blossoms of the buckwheat yield a rich supply late in the season, but the honey is darker in colour, and never so finely flavoured.

The splendid tulip-tree, one of the most noble of the forest-trees, is much resorted to by the bees. Its large tulip-shaped flowers (from which the tree takes its name) are beautifully variegated, though mostly of a pale yellow colour. About the middle of May they are in full bloom, and the bees are then most actively engaged in gathering from them large stores of honey.

But we must not forget the graceful willow-tree; which is most important to the bee in the early spring. It puts forth its tender shoots when almost every other tree has still a barren and wintry-like appearance. Even then, on a mild and sunny day, if standing under the spreading branches of some stately willow, you might fancy yourself by the side of a populous beehive, so loud is the humming sound which falls upon your ear. Look up, then, and you will perceive over your head a vast army of bees, their motions so rapid, that they seem never to rest for a moment, darting to and fro every where among the branches. 
Though the busy bees are usually so cautious, they have been, but very rarely, known to collect honey of a poisonous nature. Some persons are said to have lost their lives, many years ago, from eating honey which it was ascertained had been collected by the bees from the flowers of the wild laurel, a shrub very common in America. Perhaps it was not easy for them to procure a plentiful supply of food, when they were thus tempted to partake of that which rendered their honey injurious for the use of man. It is not known that this honey was hurtful to the bee itself.

"Give thee good-morrow, busy bee !

No cloud is in the sky;

The ring-dove skims across the lea,

The tuneful lark sours high;

Gay sunbeams fall on dewy flower,

Slight breeezes stir the tree,

And sweet is thine own fragrant bower-

Good-morrow, busy bee!

"Give thee gool-even, busy bee !

The summer day is by;

Now droning beetles haunt the lea,

And shrieking plovers cry; 
The light hath paled on leaf and flower, The chill wind shakes the tree; And thou, well laden, hast left thy bower- -

Good-even, busy bee!" 


\section{CHAPTER IV.}

POLLEN-PROPOLIS-DIVISION OF LABOUR AMONG THE BEES.

Another part of the labour of the bee is to gather the pollen, or farina, from the flowers; and for this it is as well prepared as it is to secure the nectar. While the bee is busy in lapping up the honey from the nectary, its body becomes thickly covered with the fine dust from the little knobs or boxes, called anthers, supported by the filament in the centre of the flower; or, often, they roll their bodies in the flower-cup, on purpose to obtain its farina. This dust the bee wipes all off, with the brushes of her legs; not carelessly, as we brush our dusty clothes, merely to make them clean, dispersing the dust in the air, but collecting every particle of it together, and then kneading it into little balls. The pollen when thus kneaded is called bee- 
bread. Mixed with honey, it forms the food with which the young worms are fed in their cells.

Let us look at another wonderful contrivance with which this little insect is furnished. In the middle of

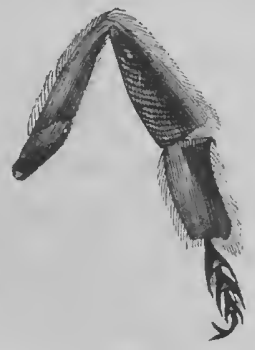

Hind Leg of the Bee.

the hind pair of the bee's legs there is formed a kind of basket; the bottom of a smooth shining substance, like horn, and surrounded by strong thickly-set hairs. Whatever the bee places in these baskets, is prevented from falling out by the hairs or bristles around the edge. She may even heap up the load above the top of the basket, and it will not fall. Into each of these she 
puts the little balls or pellets of pollen, and conveys them to the hive, as safely as the eggs we buy at market are carried home in our baskets. The bee-bread is even more necessary than the honey for the nourishment of the young family in the hive.

The most abundant gathering of pollen takes place in the spring, for the wants of the young brood; but the bees continue to collect it throughout the summer, not only for present use, but for storing up against a season when it cannot be obtained out of the hive. The bees always prefer the early morning, before the heat of the sun becomes great, to collect the pollen; for then the dew and moisture on the flower renders it more easy for them to mould the little balls and pack them into their baskets.

The little bee, thus returning with its load, is sometimes met at the entrance of the hive by the nursingbees, who relieve her at once of a part or of all that slie has brought home; or she enters the hive, and walks about for a few moments; always, whether standing or walking, beating with her wings and making a noise, as if to call her companions around her. 
Three or four bees, or frequently many more, go to her, and begin to lighten her load, each taking small pieces in their mouths, and carrying them away to feed the young worms, till the whole is gone.

Whatever is collected more than is wanted for present use for food, they deposit in cells in which there is neither honey nor brood. To do this, the bee who carries the loaded baskets places her middle and hind legs firmly on the edges of the cell, and with her fore legs pushes off her load, dropping it into the cell. Perhaps because she is too much fatigued, another worker-bee then instantly puts its head into this cell and keeps it there for a short time, working on the balls, softening and kneading them; probably mixing with the pollen a little honey, and packing it quite close into the cell. Sometimes the industrious bees provide so great a quantity of this bread as to fill a large number of their cells with it. It is dark-coloured when in the comb, very bitter to the taste, and not much admired by those who are fond of honey.

In the spring of the year, when the bees first begin their work, scarcely a single labourer will be seen re- 
turning to the hive without these balls or pellets of pollen in its baskets. The balls are always of the same colour as the anther-dust of the flowers from which it is collected, most commonly the various shades of yellow, pale greenish-yellow, or deep orange. As the bee visits but one species of flower on each journey from the hive, the different kinds of pollen are never mixed, but the balls are of one uniform colour.

The propolis, of which the bees make much use, is a gummy substance, of a reddish brown colour; it is soft, will pull out in a long thread, and has a fragrant, balsamic smell. The bees obtain it from various trees, and carry it home in their baskets. The leafbuds of the poplar, the pine, the birch, and the alder, all yield a gluey gum-like juice of this description. The propolis is used by the bees to stop up every crack and crevice in the hive, through which cold, or wet, or any enemy might enter, and also in finishing and varnishing over the cell-work of their combs.

The bees do not confine themselves in their excursions to the gardens and fields immediately around 
the hive; but, if attracted by the scent of honey, they fly off quite a distance from their home. Thcir sense of smell is very acute, and enables them to discover the honey hid entirely from sight, in the depth of the richest blossoms. They fly very rapidly, probably at the rate of twenty miles an hour, and pass in and out of the hive, on their journeys, many times in a day. In plcasant weather, the number that return to a wellfilled hive with their burden is often a hundred in a minutc. It is said that a hive containing a family of ten thousand workers will collect in one season fifty pounds of bee-bread, beside their stock of honey, the propolis they gather, and the attention they give to all the other work of the hive.

There is a division of labour in all respects among the bees. While a part are ernployed in collecting honey and pollen, others may be engaged in bringing home the propolis; some are wax-makers, others are sculpture and nurse-bees. The bees of the same family are said never to disagree or interfere with each other's business, and none meddle with what does not belong to them, but each attends actively and 
quietly to its own work. At the same time, they are kind to each other, and always willing to share with each other the fruit of their toil.

May we not look upon the little bee as, in these things, affording an example to each of us? Are all these good habits observed by us in our families, and do we consider the wants and the happiness of those whom we love, as placed much in our care? We may go to the bee, as well as to the ant, and learn lessons of true wisdom!

How carefully does the little creature attend to all the duties appointed her! She wastes nothing of the materials for her work, or of the time granted her to labour, but goes on to lay up a store of provisions for a time of need, rather than to enjoy in idle pleasure the sunny day and the present hour. We should never let plenty tempt us to be wasteful and extravagant; and, especially, we cannot value too highly the time present, as a means of improvement. It is all that is ours. The season of youth is to the young as the early spring-time and the bright days of summer to the bee! She must then gather her store, or not 
at all. Youth is the favourable season for gaining knowledge; yet it is swiftly passing away. "The hand of the diligent maketh rich," in the acquirement of every thing really valuable and enduring.

"Come, honey-bee, with thy busy hum, To the fragrant tufts of the wild thymo come, And sip the sweet dew from the cowslip's head, From the lily's bell and the violet's bed.

Come, honey-bee,

There is spread for thee

A rich repast, in wood and field,

And a thousand flowers,

Within our bowers,

To thee their nectar'd essence yield.

"Come, honey-bee, to our woodlands come; There's a lesson for us in thy busy hum; Thou hast treasure in store in the hawthorn's wreath, In the golden broom and the purple heath;

And flowers less fair,

That scent the air,

Like pleasant friends, drop balm for thee,

And thou winnest spoil

By thy daily toil,

Thou patient, and thrifty, and diligent bee. 
"We may learn from the bee the wise man's lore,

"The hand of the diligent gathereth store;"

He plies in his calling from morn till night,

Nor tires in his labour, nor flags in his flight;

From numberless blossoms of every hue,

He gathers the nectar and sips the dew;

Then homeward he speeds

O'er the fragrant meads,

And he hums, as he goes, his thankful lay:

Let our thanks, too, arise

For our daily supplies,

As homeward and heavenward we haste on our way." 


\section{CHAPTER V.}

\section{THE HIVE-TIIE HONEYCONB.}

The hives, of various kinds, of different size and shape, which we provide for the use of the bees, are not essential to their labours. They could do without all that we do for them, as we have seen in the case of the wild-bees, and build their city in a hollow tree, or any other place they like, where they could find room. But we are very willing to furnish them with a home, neat and pretty in appearance, and convenient in arrangement, in order that we may obtain in return from them the sweets they prepare so skilfully. Hives are now so contrived that honey may be taken from the bees without killing them to obtain it; and this cruel practice, formerly so common, is now almost entirely dispensed with. Then thousands of flourishing families of bees were every year entirely destroyed, 
that their owner might get possession of all the contents of their hive. Truly, it could then be said to the poor bee,-

"Ah ! what to thee is summer's golden smile?

And what to thee the flower-enamelled plane?

Will gratitude reward thy daily toil?

No, no; thou workest for reward in vain.

"Not long the hive of treasure will be thine;

Rapacity will force thy little door;

Those treasures, with thy life, thou must resign,-

A breathless victim on thy fragrant store!"

The inside of a bee-hive contains many wonders; it is a city on a small scale, with its regular streets and dwellings, built on the most perfect plan that could possibly have been contrived for the use of the inhabitants. Some of these buildings are store-houses for food; in some, the citizers live; and a few, more spacious than the rest, are the cradles of the sovereigus or mothers of the hive. What could you have more? But the material of which this city is built is one which man, with all his skill and his knowledge, knows not 
how to produce; and the city itself, the wisest builder among us could not have planned with more wisdom. Yet, this is the work of a society of curious insects; and all the wonders which they perform' we cannot fully understand, with all the powers of reason which we enjoy. IIe who careth for the raven, and heareth its cry for food, careth also for the little bee. From Him came all its gifts, as we have received from the same kind hand every thing we call our own. Here we are on a level with the inferior creatures of His power; but, oh, how raised above them in the possession of a soul, in the gift of immortality!

You have many times seen a piece of honeycomb. It is a flattish cake, composed of two ranges of cells, backed against each other, with a partition between, which is the floor of each range. The cells stand side by side, the two ranges in the same piece of comb thus opening exactly opposite to each other into the streets running between the combs. A well-filled hive contains many of these ranges or combs. 


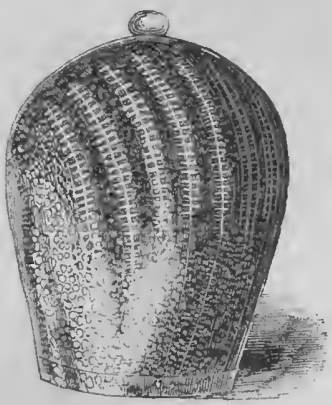

Arrangement of the Combs, as seen in a Glass Hive.

The combs are about half an inch apart, leaving the passage between wide enough to allow two bees to work on cells opposite to each other at the same time if necessary, and to pass each other freely without disturbance. There are also openings left through different parts of the combs, forming short streets or cross-cuts, for the bees to save their time in going round.

The shape of each cell in the comb is that of a D 
$\Xi 0$ TIIE HIVE AND ITS WONDFRS.

hexagon, as it is called, having six equal sides. No other shape would do nearly so well to save room, to

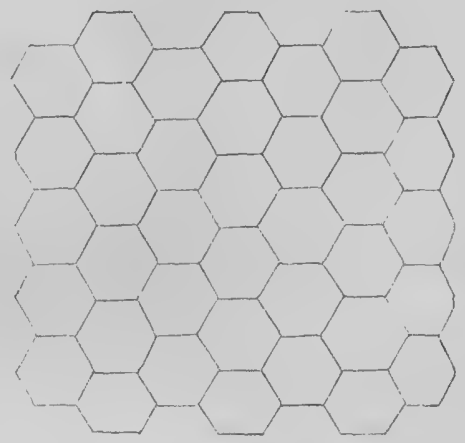

give the greatest strength, to save the wax used in building the cells. Their sides fit into each other as no other shape would.

If the cells had been quite round, which seems best suited to the shape of the insect, there would have been room wasted in joining them together, as you will see by comparing the following figure with that on the 
previous page, which is the real shape of the cells. If

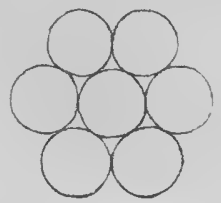

they were made square, or in a triangle having three sides, they would fit as closely together as they do in the hexagon or six-sided figure; but then there would be waste at the corners, more wax would be needed to build them, and at last they would not be so convenient for the use of an insect with a round body, like that of the bee. But in taking the shape with the six sides, every difficulty is removed.

Another important saving of wax, as well as room, is gained by making one common partition serve as the floor for two ranges of cells. Had they been formed in single ranges only, opening but on one side, and streets between, more room would have been required, and more material for building. 
Each cell would be weaker, too, had it stood alone, and separate from other cells; while all are strengthened by their close union with each other. Both the sides and bottoms of the cells are thin as a sheet of fine writing paper; and as walls so thin would be always crumbling and breaking at the edge, from the passing in and out of the bees, they make a ledge or border round each cell at least three times thicker than the sides.

If we examine the floor of these cells, which is the division between the two ranges of cells in the same cake of comb, we shall find it not flat, or a straight line, but somewhat of the following form, WWW; and the floor of each cell has three sloping sides, meeting in a point in the centre. The bottom of a cell in one range of combs is not therefore the bottom of the cell on the opposite side of the comb, but portions of three cells on one side meet in the centre of the other. Thus the bottom of each cell rests against the point where three partitions meet on the other side, and is supported by the walls of the cell opposite, which gives it all the strength possible, while 
this is exactly the best plan to save the wax and the room.

The following figure will perhaps assist you, though
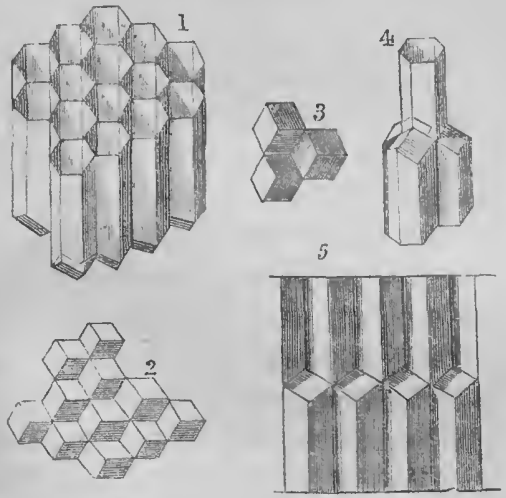

[1. Cluster of cells from one side of the comb. 2. Plan of the bottom of the cells. 3. Plan of three cells of one range, showing how the bottom of a single opposite cell is formed. 4. Four cells, three on one side, and one on the opposite side, showing the manner in which they join. 5 . Plan of two rows of cells.] 
it may be difficult clearly to understand the curious formation of these cells; but it is most true that the bee seems to know those delicate points which have required nuch time and study for the most learned men to discover :-

This problem was once given to a celebrated mathenatician, viz., to show how a certain portion of wax could be made to form cells of the same size and shape, so as to give the greaiest strength and the most room, and at the same time to use the smallest quantity of the material. After trying the question by the strictest rules of geometry, the answer proved that the bees had acted as if acquainted with all these principles, and had, in the most simple and perfect manner, secured every advantage of arrangement in the building of their cells. How marvellous is it that to a poor little insect, so trifling in the sight of man, the Maker of all things should have given such wonderful powers! We must be blind, indeed, if we, who observe these things, perceive not in them something of "the loving-kindness of the Lord!" 
"Great God! how endless is thy love?

Thy gifts are every evening new ;

And morning mercies from above

Gently distil, like early dew.

"I yield my powers to thy command;

To thee I consecrate my days;

Perpetual blessings from thy hand

Demand perpetual songs of praise." 


\section{CHAPTER VI.}

WAX-BUILDING THE CONB.

Tre substance of which the honeycomb is formed is wax. But where do the bees procure this material? And how do they use it in their work? The wax is produced from the honey or other sweet, which the wax-maker bees have taken into their honey-bags. It first appears, formed in the shape of little scales, between the segments or rings of the body of the bee, on the under side, when she is preparing to build her comb. The production of the wax by the bee is very singular, and for a long time it was scarcely at all understood.

When a swarm of bees go from an old hive to take possession of a new one, they always go laden plentifully with honey. There are several advantages in this course of the bees, which we may clearly perceive. 
The first is, that when they are filled with honey they are always good-tempered, and are seldom, if ever, known to sting. They are thus easily managed by the person whose place it is to hive them, as it is called; and even if they settle on him he has little to fear, as, unless really injured, or especially provoked, not a single bee will harm him. Then, in case of stormy weather occurring, and continuing for two or three days, so that the bees cannot go out for their food, this honey which they carry with them is most useful to them, and, indeed, prevents them from starving and perishing with hunger. Then, again, they take this honey with them in order that they may be prepared with the wax and have it ready for building the comb.

The wax-makers thus furnished with their portion of sweet for their proposed work, they begin by suspending themselves in garlands or festoons from the roof of the hive. In a glass hive, thin slips of wood have sometimes been fastened with glue to the arch of the hive, at a little distance apart, as a support to the bees, because of the smoothness of the glass. 
58 TUE IIVE AND ITS WONDERS.

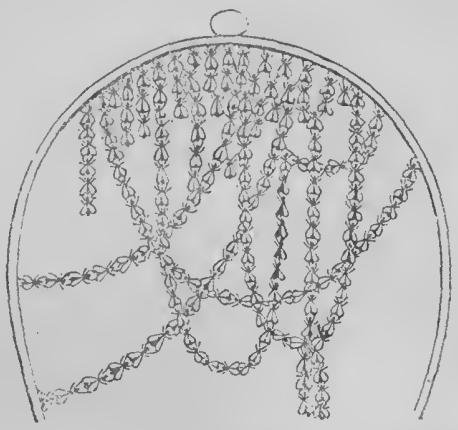

Festoons of Bees, suspended from the roof of the Hive.

Those who first reach the top, fix themselves there by the fore-feet; others, scrambling up the sides, join them by taking hold with their fore-feet of the hindlegs of the first; and thus they form a kind of chain, fastened by the two ends to the top of the hive, and serving as ladders or a bridge, to assist others in ascending. Thus they continue to arrange themselves; the festoons crossing the hive in various directions, or falling gracefully down from the roof; at length form- 
ing in the centre a thick cluster of bees, and hanging from the top to the bottom of the hive.

One object of the bees, in thus clustering together, is doubtless to raise the temperature of the hive, to make it so warm that the wax will soften sufficiently for them to work with it, and use it as they wish. Wax in hard, dry scales, and in a cool place, it would be difficult for them to manage.

After arranging themselves in the manner described, the wax-makers remain .quiet and motionless for nearly twenty-four hours. During this time the wax is forming; and at length it appears in thin scales on the under part of the body, between the rings. These scales of wax are secreted or separated from the honey or syrup of sugar, which the bee had previously taken into her honey-bag.

When the wax is formed and ready for use, a single worker disengages itself from one of the inner festoons of the cluster, and makes its way to the roof of the hive, to begin the comb. It fixes itself near the centre, and then turns around, and, with its liead, drives away the other bees, till a clear space is made, 


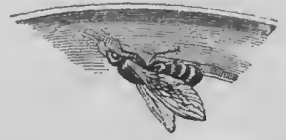

Wax-maker laying the Foundation of a Comb.

an inch or more in size, where it can move freely. This bee is the founder of the comb.

The worker-bee is provided with a pair of pincers at the joint of her hind-legs; with these she now seizes a scale of the wax formed under her body, and, drawing it forward with the claws of the fore-legs, conveys it to her mouth. Here she breaks the little scale into pieces, softening it all the time with a frothy liquid from her tongue. This gives it a whiteness and clearness which it had not before; and it comes out of the mouth of the bee in the form of a very narrow ribbon. Then she takes it up again with her claws, moistens it once more, works it over, and passes it a second time from her mouth, but in an opposite direction. Throughout this process, the tongue of the bee, as she applies it to the wax, puts on various 
shapes : sometimes it is flat, like a trowel, and sometimes pointed, as a pencil.

When the particles of wax are thus softened and prepared, the worker-bee, who is about to begin the comb, places them against the roof of the hive, arranging them as she pleases with the point of her jaws. She then takes a second scale from her body and employs it in the same manner, uniting the particles with those of the first; and again a third, until she has disposed of all she has; when she quits her work and disappears among her companions.

Another bee, with wax under her rings, now leaves the cluster, and, suspending itself to the same spot, and taking out a scale with the pincers of her hindlegs, passes it into her mouth, and goes on with her work in the same way, joining her prepared wax to the other, and placing it in a line with the deposit made by the first bee. A third succeeds; then another; all following one and the same course, till a little low partition of wax, two-thirds of an inch in length, and about two-thirds of the height of a cell, is formed against the roof of the bive. If any particle 
of the wax is placed improperly by one bee, the next coming removes it to the proper place.

Thus the foundation of the cells is laid; but no trace of their shape or size is yet to be seen. The work is now to be taken up by another set of bees. You have seen the masons engaged in building the walls of a house, and the labourers supplying them with the loads of brick or stone and mortar, necessary for carrying on their work. We may call the first bees the labourers, who prepare and convey the stone and the mortar; and after them come the masons, who are to use the materials in building the house. The waxmakers are worker-bees; they prepare the wax and lay the foundation; the nurse or sculpture--bees are workers also, and they follow to construct the cells.

No sooner is the little mass of wax large enough to admit a nurse or sculpture-bee between the waxmakers, than they begin their work; at first, a single bee alone, as before. On one side of the waxen wall it makes a hollow with its jaws, which is about the size, and is intended for the bottom of a single cell. When it has worked some minutes, it retires, and an- 
other bee follows, making the cavity deeper, by raising up the walls around it and giving them a more upright form. When this cell is partly finished, two others are begun at the back of it, and another on each side; and thus the work goes on till, by degrees, the whole is completed.

The uppermost range of cells, by which the comb is fastened to the top of the hive, differs from all the rest. These alone have but five sides; the side next the roof being much broader than the rest; it is by this means fastened more securely than it could be otherwise. The bees appear to judge of the quality and fitness of all their work by means of their antenne or feelers. Every particle of wax they use they feel over with these organs, which are so flexible and delicate, that they are to them in the place of eyes and hands; they scrve as compasses and measures, and guide them in every part of their work. They are averse to light, and quickly close up every chink in their hive by which it could enter. In the darkness the bee builds her comb, fills the cells with honey, feeds her young, and attends to all their wants. 
Although so many thousand bees are at work, they never begin foundations for combs in several places at once, without any order; but when some rorvs of cells are formed on the first, other foundations are laid on each side of that first begun. The middle comb is always, however, built out beyond the others, and is a guide in shaping those which come after.

While the cells are building, they appear to be of a dull white colour; the wax is soft, and not quite smooth; but in a few days, a yellow tint is spread over them, particularly at the edges, which become thicker and firmer, less brittle, and more solid. Before this, the comb would crumble and break at the slightest touch. This is called the varnishing of the cells, or covering them with the peculiar substance called propolis; but that which gives the yellow colouring to the wax is not yet known.

The cells of the honeycomb are used for storing honey and bee-bread, and for cradles for the young bees. The cells in which the workers are reared are begun first; they never vary in size. They are smaller than those for the drones. The drone-cells 
are generally placed in the middle or sides of the comb; seldom in the upper part. The royal-cells for the queens are built last of all. Of these there are usually four or five, and sometimes ten or twelve in a hive. When a queen has come forth, the cell is partially eaten away by the bees, and reduced in size, so as to resemble an acorn-cup in shape, and they fill up the space with a row of common cells, that no room may be lost.

In the formation of the comb, some variations have at times taken place, quite as remarkable as the uniform manner in which they are usually built. When a stick has been thrust through the middle of a hive, for the convenience of lifting it, or for any other reason, disturbing the bees in their work, and changing the shape of their comb, they repair the defect by making a piece of comb, longer or shorter, of the size that may be required to fill up the vacancy. When honey is very abundant, they enlarge the size of their honey-cells in a part of the hive; or, if there is not time to do this, they add a rim of wax to them, tọ increase their depth. 


\section{6}

THE HIVE AND ITS WONDERS.

\section{SONG OF THE BEES.}

"We watch for the light of the morning to break, And colour the eastern sky With its blended hues of saffron and lake; Then say to each other, "Awake! awake ! For our winter's honey is all to make, And our bread, for a long supply.'

"And off we hie to the hill and dell, To the field, to the meadow and bower, To dip in the lily with snow-white bell, To search for the balm in its fragrant cell,

The mint and the rosemary flower.

"While each, on the good of her sister bent, Is busy, and cares for all, We hope for an evening of heart's content, In the winter of life, without lament That summer is gone, or its hours misspent, And the harvest is past recall." 


\section{CHAPTER VII.}

TIIE QUEEN-CARE OF THE YOUNG.

Tire queen of the bee-hive is a most important personage. The fondness and affection of her subjects for their sovereign is quite wonderful. As she moves about the hive, with a slow and dignified step, she is attended by a guard of workers. They take this duty by turns. Wherever she goes, they clear her - path, turning their faces towards her with the greatest politeness. When she rests from her labours, they approach her with respect, they lick her face, they offer her honey, and seem disposed to render lier every kind office.

Sometimes a stranger queen attempts to enter a hive, when the workers, who are always on the watch, fall at once upon her, seize her with their jaws by the 
legs or wings, and close in all around her, so that it is impossible for her to move farther. Other bees then come to their assistance from the interior of the hive, and encirele her still more closely, all with their heads towards the ceutre where she remains. If they keep her thus a prisoner long, she will die, from want of air or food, but they never sting her to death. They appear sometimes to eneourage the meeting of the stranger with their own queen, and permit them to fight, when the rightful sovereign, rushing upon the other, usually despatches her with one stroke of her sting.

When a queen dies, or when she is removed from the hive, the bees do not at first seem to pereeive it, and continue their labours as usual. But in a few hours afterward, they appear disturbed near the spot whieh the queen had oeeupied: the movement soon spreads, and many of the bees leave their work, forsake the young, and run here and there in great alarm. As the bees meet each other in the hive, they stop and cross their horns, or antennæ; those who first heard the sad story of their loss seem telling the other bees, 
by gently tapping them with these slender but wondrous parts of their bodies.

Thus the tidings circulate till the whole hive is in confusion. The workers run over the combs, and against each other in hurry and disorder, rush to the entrance of the hive, return and spread themselves around, then go out again, and again return. The hum within the hive becomes peculiarly mournful and sad, and thus it continues for several hours; when they begin to be quiet once more, they return to their work, and soon take steps to repair their loss.

If a stranger queen from another hive is given to the bees, in a shorter period than twelve hours after their loss, they will not receive her as their sovereign, but treat her as they would a stranger at any other time. But if twice that number of hours have passed by since they lost their queen, when a new one is introduced, it is singular that they seem then to have forgotten their former monarch so far as to be willing to adopt another.

The moment this stranger is placed upon a comb, the workers who are near first touch her with their 
antennæ, and then pass them all orer her body, when they retire and give room to others, who salute her in the same manner, and give her honey to eat. All then beat their wings at the same time, and range themselves in a circle round her. $\mathbf{A}$ general agitation seems to pass through the hive; many others draw near, touch the stranger, offer her honey, and fall behind again, all continuing to vibrate their wings. At last she moves, and the circle opens to let her pass; then they follow her, surround her with a guard, and soon she appears acknowledged queen in all parts of the hive, and begins to lay her eggs.

The royal bees are never hatched more than one at a time; and, unless they have need of them to lead out a swarm, the workers keep them in confinement in their cells (covering them with lids of wax), to prevent them from killing each other, or being killed by the reigning queen. As they must be fed, they make a small hole in the waxen lid, through which the captive queen thrusts her tongue and receives her food from the nurse-bees. While in this confinement, she utters a low complaining note. 
While the workers thus prevent the young queens from leaving their cells more than one at the same time, when they need a sovereign for their hive, or to conduct a swarm, they always set free the eldest first. Probably, they know their age by the noise which these little creatures make while they are covered up in their cells; this noise becoming sharper and louder as they grow older and increase in strength. This sound is supposed to be caused by the vibration of the wings of the bee in her cell.

It is a remarkable fact, that if the death of a queen should occur, no eggs being left in the royal cells, the bees can at once supply her place, if she left workereggs in the cells, or their larvæ less than four days old. To do this, they select one or more from the young worker brood, and make a royal cell or cradle for them, by tearing down the partition between, and throwing three common cells into one; afterwards making it larger and deeper. The chosen grub is then plentifully fed with the royal jelly, or the food of the queens, which is much more sharp and biting in taste than that given to other bees. Thus cradled 
and thus fed, the insect leaves its cell, at length, a queen, although otherwise it would have been a common worker-bee! If, by this wonderful provision, the bees were not able, when necessary, to supply the loss of a queen, the whole society might be lost entirely, and in time the insect disappear from our globe!

The care of the bees for their young brood is very great, and nothing excites their anger so much as to meddlc with them. In a new hive, they first prepare the cells which are to serve as cradles for the young; and they collect very little honey till aftcr they have laid up an ample store of bee-bread for their food. By watching them in the spring-timc, you may see them constantly returning, one after another, in rapid succession, alighting on the board in front of the hive, their baskets filled with the treasure they have gathered by flying from flower to flower, brushing from the stamens the soft dust and kneading it into balls. They quickly dcposit the contents of their baskets and go back for a new load.

This bee-bread is carefully stored up, and kept until the eggs are hatched which the queen-bee has laid in 
the different cells, when the little worms or larvæ are fed by those of the workers who are nurse-bees. They put their heads into each cell containing the young worms while they feed them, and then pass on to the next. Others coming by, look in, and, appearing to see with a glance that all is right, do nothing unless they find a cell where some food is needed. This food the nurse-bees adapt to the different ages of the young ones; and for the youngest it is made very simple and insipid, as suited to their taste.

Thus, all are nursed and fed till they are ready to spin their cocoons; and so careful are the bees of the quantity of food they give out, that not a particle is left behind to be wasted when the young bees come forth from their cells. The food of the royal young bees is quite different from that with which the workers and drones are fed.

"Thou wert out betimes thou busy, busy bee!

When abroad I took my early way;

Before the cow from her resting-place

Had risen up, and left her trace

On the meadow with dew so grey,

I saw thee then, thou busy, busy bee! 


\section{4}

\section{THE IIIVE AND ITS WONDERS,}

"Thou wert alive thou busy, busy bee!

When the crowd in their sleep were dead;

Thou wert abroad in the freshest hour, When the sweetest odour comes from the flower:

Man will not learn to leave his bed, And be wise and copy thee, thou busy, busy bee!

"Art thou a miser, thou busy, busy bee?

Late and a ly at employ;

Still on thy golden stores intent, Thy summer in heaping and hoarding is spent,

What thy winter may never enjoy:

Wise lesson thus for me, thou busy, busy bee!" 


\section{CHAPTER VIII.}

SWARMING OF THE BEES.

Tne bee of most consequence in all the hive is, of course, the royal mother and head of all, the queen. She is always the leader of a new swarm. The swarming of the bees is very singular. It occurs when the bee family has become too large for the hive. They then send off a colony to seek a new home for themselves. If their owner has provided a proper and convenient place for them, they may generally be induced to occupy it ; thus, they are accommodated, and the is benefited by the increase of the number of his hives.

In the spring, when the weather begins to be settled and warm, the first swarm usually goes forth. The hive is then well stocked with eggs, and is likely to become crowded. If plenty of room is given to the bees, they do not often swarm. The best swarms are 
those which leave the hive early in the season; as if it is later than June, they have not time to build their comb and to provide themselves with sufficient food for the next winter: while a strong, active swarm, going off early, will make honey enough for the use of the hive, and some to spare for their owner. They have even been known themselves to send off a new swarm in the same season. For these reasons, the very early swarms are always highly valued by the keeper of bees.

The first swarm of the season is led by the old queen, after she has laid a great number of eggs in the different cells of the hive. When the young larva in the royal cells are nearly ready to come forth and appear in the hive, the queen-mother leaves it, taking along with her a swarm. More than one queen is never suffered to live at the same time in the hive, and she is really obliged, as it were, to leave her old home. If she were to remain till the young queens left their cells, none of them would be saved; for she having so much more strength than they, would destroy them in succession, as soon as they appeared.

After the old queen has conducted the first swarm 
from the hive, the remaining bees take particular care of the young ones in the royal cells, especially to prevent them from leaving the cells as they are hatched, except at intervals of several days. At length, the female hatched from the egg laid earliest leaves her cell, and at first the workers appear to treat her with indifference. But she seems immediately to feel the greatest anxiety to destroy those who are her rivals, and she tries to get at them in their cradles, but the workers will not allow her. No sooner does she approach than they bite, pull, and worry her, till she is forced to remove; and thus she goes from one royal cell to another, scarcely finding a place of rest for a moment. She passes through the different groups of workers, very much agitated, and at length a general confusion takes place. In a few minutes, notice seems to have reached all the bees, the young queen rushes towards the door, a crowd follow after her, and the second swarm passes out of the hive. The same circumstances may even occur again, when another queen is set at liberty, and a third colony may go out from the old hive, in the same scason. 
When the bees leave the hive, they hover for a few moments around it, as if to give time for all who wish to join them, and then fly into the air. They do not often rise very high, but most frequently settle on the limb of some tree, not very far from their old dwelling. On whatever branch the queen chooses to alight, the bees are sure to follow. 'There they are soon formed into a cluster, hanging from the bough in a most singulisr manner, clinging to each other by their feet, with their heads up. This living cluster looks quite like a solid mass, of a dark brown colour, usually about the size of the crown of a man's hat, but its shape that of a cone with its top downwards. If the queen is safely with them, they soon become perfectly quiet in this spot; but if from any cause she is separated from them (as sometimes happens), they will search for her, and if they cannot find her, they scatter, and every bee returns to the hive.

This curious cluster of bees, their queen remaining with then, will often continue for hours clinging to each other, and to the branch of the tree where they have settled; but sometimes not so long, particularly 
if they have gone off from the hive in the heat of the day. When they have waited a certain time, if no attention is paid to them, they will rise in a body, and fly off to some distant spot, perhaps to a wood, if any is near, where they may take possession of some hollow tree, and make a home for themselves. Many swarms are lost in this manner every season, from want of proper foresight and care.

But the bees, before they leave the hive, have usually sent scouts or spies before them to look out a new place for them. If this has been selected at a distance from their old home, they do not alight at all near, but fly away so far, that they are never seen again by their owner. Their flight is very direct, in a straight line to the point where they rest; but, in general, their alighting place is near, and within reach. If it were not so, their future labours might be all lost to man ; but in kindness the Creator has so ordered it, that they are most frequently still detained under lis care, that he may be profited by their industry and skill.

Very often, those persons who are interested in the bees are watching their motions at the time of swarm- 
ing. When, on a bright sunny morning, very favourable for their work, they do not go out as usual, but seem restless and uneasy, running about in every direction, or gathering in clusters at the door of the hive, it is supposed that a sivarm will soon leave. This is not always the case, as the heat may occasion the restlessness of the bees; but when a general buzz or hum is heard at intervals for several days from the hive, and all within seems bustle and movement, the bees are probably preparing for their departure. They are then watched more carefully than before. Immediately before the swarming, a still louder hum is heard, and then they rush suddenly to the outlet of the hive and depart.

If they settle on a tree near at hand, as soon as it is perceived that they are quiet, preparation is made to hive them. They first get ready a clean new hive, then place a table, covered with a cloth or blanket, under the limb of the tree where they are clustering, and some skilful person, not afraid of the little creatures, takes up the empty hive, holds it bottom upwards direetly under the bees, and shaking the bough 
a little they nearly all fall into it. The hive is then set down upon the table, with one or more of its sides raised on small blocks, to admit such of the bees as are still outside.

Some persons prefer to place the hive on the table with one side raised, and shaking and brushing the bees on to the table directly before it, when they soon perceive it and enter it at once; or, if a few take wing, or settle on the outside of the hive at first, they return and follow their companions. When nearly all appear to have entered, the hive is removed to the place it is to occupy, commonly ranged in order with the other hives. The bees are soon at home in their new dwelling, and begin to prepare their wax and build their comb.

How remarkable is the change which has now taken place in these curious insects, by which they are impelled to return no more to their former abode! Its location is not altered. There it stands in the same spot: to us it appears unchanged! Yet the little creature is never, by any mishap or mistake, or sudden surprise, again led to enter its door. Its new 
home has now all the attraction; there is its queen, its family there, and it has no further interest in its old habitation.

But the parent hive is not left empty after the departure of the swarm. The bees which emigrate are not always the youth of the colony; many of these remain, and others are hatched from the stock of eggs of workers, which the queen has always left in the cells. At the time when the swarm went off, some of the bees were abroad at their work, ranging through the country, and these return in the evening, and form, with those left in the hive, quite a large family still. In two or three days' time, perfect order is restored, the nursing-bees attend to their proper business, taking charge of the young, and watching the cells containing the future queens.

Sometimes the eldest of the young queens is allowed to destroy all the others; there will then be no swarms after the first of the season. But when several swarms have left the hive, and no more bees remain than are required to sustain the family, there is no longer any anxiety shown about the royal brood, the workers 
permit the cells to be torn open by the first-born queen, and either drag out the young themselves, or suffer her to kill them.

The bees are very careful not to leave the hive in a swarm unless the weather is fine, and a shower of rain will sometimes keep them back for a whole day. 


\section{CHAPTER IX.}

NEATNESS OF TIE BEE-VENTILATION OF THE HIVEENEMIES OF TIIE BEE.

True little bees are extremely neat in their persons and in their houses. They remove from the hive, as quickly as possible, all dead insects, or any thing of the kind which is light enough for them to drag out with their mouth. If they cannot remove it, if still alive, they attack, sting it to death, and then embalm it, covering its body with propolis, so that it cannot become offensive.

A poor snail, with a shell on its back, having crept into a hive early one morning, crawled about for some time, till at last, by means of its own slime, it stuck fast to one of the panes of glass, where the bees found it. They immediately surrounded it; but as it was so large that they were not able to remove it, 
and on account of the hardness of its shell, they could not destroy it, they formed a border of propolis round the whole edge of the shell, fastening it securely and perfectly down, and leaving the creature within to perish.

Some bees once finding in their hive a houseless snail, or one without a shell, fell upon it as soon as they saw it, and pierced it with their stings till it died beneath their strokes. After this, as it was not possible to remove its body, they proceeded to embalm it entire, covering it all over with a coat of propolis.

This attention to cleanliness is rendered very necessary for the bees, from the confined space within the hive, and the multitude of active laborious individuals it contains. All the cracks or openings, too, they have closed up with propolis, and the door of entrance is very small. This door, which is the only opening for the admission of air, is often much filled up by the bees themselves in departing to their work, and arriving again at the hive on their return. The air within is of course affected by these things; but in 
order to prevent it, so far as they can, and to keep it sweet and clean, these little creatures have a most remarkable contrivance. The workers ventilate the hive by means of a fan! They cool themselves and purify the hive in the sultry days of summer, and even at other seasons, by the use of a fan !

To do this they arrange themselves in regular order, chiefly on the floor of the bive. Here they stand in rows, extending from the front towards the back part; some outside of the entrance, with their heads turned to it; those within having them always turned in the opposite direction. They then unite their wings by the hooks at their extremity into one piece, and flap them up and down as ladies do a fan. The motion is so rapid that the wings can scarcely be seen while it is going on, and a pleasant buzzing sound may be constantly heard by the listener outside of the hive. When one set of workers is fatigued with the exercise and retires, another takes its place; and the current of fresh air thus brought into the hive is so important to the family of bees, that without it they could not live. They are oppressed by the heat of the 
sun, especially should it shine directly upon the hive ; and when the closeness of the atmosphere requires it, they are taught thus to provide for the circulation of the air!

Water, during the spring and summer, is quite essential to the little bees in their labours, as well as air. They must have drink ; and they are not always so nice about the quality of it as we might suppose they would be. They will drink the standing water in the drains and pools, not very sweet or pure, if they cannot get better. A shallow, pebbly brook is best for them, where they can drink without danger of being swept away by the high winds, as they often are on the broad, deep rivers, and drowned in great numbers. At the edge of such a clear stream, the bees nay frequently be seen taking their usual supply of cool, refreshing water.

This industrious little insect, so active, untiring, and faithful, we might imagine would be allowed peaceable possession of its home; the home fitted up with so much care and pains, and kept so neat and clean. But this is not the case: it has many enemies, 
and is often obliged to defend itself from their attacks. Sometimes the birds find them out and destroy them for food, as they do many other insects. The swallow's come and pick them up like grains of corn. The king-birds will kill thousands of them in a season. The spiders make sad havoc among them. The little ants do them much mischief by overrunning their hives; and the mice, in the cold weather, when they are inactive, will also attack them.

The wasps, so bold and strong in some countries, commit great ravages upon the becs. They are very fond of sweets, and have much love for the honey of the hive, and are so daring, that they will brave a great deal to fill themselves with the rich feast. One wasp is said to be a match for three bees; and the cunning thieves have been known to drive away a complete colony of the poor insects from their home, then take possession of it, and eat all the honey it contained.

But the most dangerous enemy of the poor bee is to be found in America, in the insect called, sometimes the wax, and sometimes the bee-moth. This 
nimble little creature is of a grey colour, and smaller than most of the millers that flit around our lights in the evening. It flies only in the night; and likes to hide itself away under some board, or in any place of shelter, during the day. It may often be seen on the outside of the hive; yet, if you attempt to put your finger upon it, it is gone in an instant.

The bees lnnow well the danger of this enemy in the dark. On a moonlight evening, in summer, you may see their sentinels keeping guard, and pacing to and fro, at the entrance of the hive, with their antennæ extended, and turning about in every direction. In the mean time, the moths are flitting about in the air, around the hive, seeking to find a moment when the bees are less watchful, that they may glide in unperceived between the sentinels. They always seek for the weakest and least populous hive, too, where they have the greater advantage. They are aware that the bees cannot see clearly in the darkness of the hive; and their only care seems to be to avoid touching those delicate feelers, which are moving about, to the right and left, in order to discover them. Wo be 
to the moth that comes within their reach; for the treacherous creature falls at once a victim to their just anger, and their anxiety to defend their property and their dwelling from his robberies.

If only one of these moths gets in, she runs up the sides of the hive and places her eggs in some close corner, or on the side of the comb. In a few days, these eggs are hatched and become small white worms. These little creatures grow very fast, feeding continually upon the combs. As soon as they are able to move, they begin to weave around themselves a silken covering for their whole bodies, open only at the head; and this is so shielded that the bees cannot sting them. In this way, they move about among the combs, all the time eating as they more, and soon increasing in numbers.

Sometimes the bees try to destroy them by fastening them up in a certain part of the comb, where they are at work, with their strong cement, the propolis; and, when they have eaten all the food within their reach, they die. But, when the moth once gets possession, the poor bee, at length, stops its labours; 
and, finally, the worm destroys every thing within the hive, overrunning it entirely. The interior of a hive, from which the bees have been driven, and which this creature has devoured, is indeed a sad sight: in place of the beautiful, delicate comb, is seen a mass of dark, loathsome fragments, fit only for the dunghill.

Another lkind of moth, in some places, troubles the bees. It is so large that it has been taken for a bat; and, from its great size, and from a certain mark on its body, has been called the death's-head hawk-moth. This moth has the power of uttering a shrill, mournful cry, which is said to produce such an effect upon the bees, that they do not attempt to molest it. To defend themselves from this creature and keep it out of the hivc, when they are annoyed by it, they build up, at the entrance, a thick wall of wax and propolis. In this wall, they leave a passage just large enough for one or two workers at a time to pass through, but which the huge moth cannot enter.

Surely, the little bee is a wise and ingenious builder: she may truly be called a cunning architect. 
" Not to myself alone,"

The heavy-laden bee doth murmuring hum,-

'Not to myself alone, from flower to tlower

I rove the wood, the garden, and the bower, And to the hive at evening weary come;

For man, for man, the luscious food I pile

With busy care,

Content if this repay my ceaseless toil-

A scanty share." " 


\section{CHAPTER X.}

STING OF THE BEE-ANGER OF BEES-ATTACK OF MISSTONARIES BY WILD-BEES.

To defend it from its enemies of every kind, and to protect its home, the bee is provided by its Creator with its powerful sting. The honey is a treasure which invites so many robbers, that its sting is given it as a necessary protection.

Yet, the honey-bee rarely uses her sting against any one, unless she is molested, or at a distance from her own home. When flying abroad in the fields and gardens, from flower to flower, she attacks no living being. How seldom are children stung, the cows, feeding quietly, or any other creature, except when near the hive. Surely, then, for its own defence, and the defence of its property, this little insect seems intrusted with so terrible a weapon. 
The bees will attack animals most fiercely, if they consider their hive in danger. Horses, left loose in the field, have sometimes strayed into the enclosure, or upon the lawn, too near the bee hives, and by accident have pushed a hive from its place: if it should be upset, death almost certainly follows to the unfortunate animals. On on occasion of this kind, the enraged bees rushed forth in such numbers, and with so much fury upon the horses, that two of them died in a short time from the effects of the stings.

The bears who inhabit forests, and vast prairies, are very fond of the wild-bees' honey, but they are much afraid of the owners of the sweets. If the bees discover them near their homes, they chase them at once, and the huge bears turn cowards and run away as fast as possible.

Those who keep bees have to be prudent in undertaking to meddle with the hives, or in disturbing the bees in their arrangements. A young lady who was fond of the care of the little creatures, and who had no fear, as they had never molested her, attempted one day to assist in raising a hive from the bench on 
which it stood, but, becoming alarmed, let go her hold too soon, and it fell upon the board, no doubt crushing some of the bees. A crowd of the angry creatures poured at once from the hive, and, though she retreated with all speed towards the house, they followed faster than she could run, and she received a number of stings upon her head and face, from which she suffered most severely. The bees, when angry, are most dangerous assailants.

When the bee is angry, she makes a shrill, loud noise, which those who are acquainted with her well understand. It is very different from her usual low, gentle hum, when returning from the fields laden with her honey, and is a note of timely warning to offenders.

The bees are very much influenced by kind and gentle treatment; as, on the contrary, they are annoyed and irritated by teazing and bad treatment. Those persons who have always shown kindness to them, they will permit to exannine their hive, remove them, and work among them, at their pleasure.

Yet it is certain that they do show a dislike to 
some persons who approach them which seems to be without cause, while they never trouble others of the same family, but allow them to work as they please about the hive. Thus, of two brothers in the same house, while one was allowed to stand by them, to look at every part of their work and to gather in the new swarms, with perfect security, the other could scarcely enter the garden where the hives stood, without danger of an attack from the partial and prejudiced bees.

A gentleman in the country had a very fine mastiff dog, and to this animal his bees had a particular dislike; they would even follow him into the house, and it was sometimes necessary to close the doors and windows to protect him from them; for the dog, though brave on other occasions, did not dare to face these littlc creatures when angry.

Of all the senses of the bee, their smell is thought to be most acute. It is most likely that by this means they distinguish one bee from another, and, it may be, different persons each from the other. Thcy have sometimes wars among themselves. A single 
bee will attack another bee, or a whole swarm carry on a furious battle with another swarm. These battles are usually occasioned by a desire of one swarm to take possession of some hive which another has occupied before them. If one of their queens should be killed in the fight, they all leave off their quarrelling, and unite together in a single swarm under the surviving queen.

There are now and then, too, robber bees, hungry and ill-behaved, who, not having collected honey enough for themselves, try to steal some from their neighbours. But, owing to a wet, cold season, or some other cause, the poor bees who do this wrong are generally half-starved for want of food to eat, and if their owner would assist them in their necessity, by placing a little trough of honey or syrup before them for a few days, they would soon leave off these pilfering tricks.

The character of the bet has not changed with years of time. Moses refers to the way in which bees are known to pursue their enemies, and to cause them to fly before them, when in the first chapter of Deute- 
ronomy, he is speaking "to all Israel on this side Jordan in the wilderness." Describing their wickedness, and the enemies which had been sent upon them, he says, "And the Anworites, which dwelt in that mountain, came out against you, and chased you, as bees do, and destroyed you in Seir, even unto Hormah."

In the year 1525, as we are told by a historian, during the confusion of a war which raged in a part of Germany, a mob of peasants assembled and determined to pillage the house of the minister of Elende. The unoffending man used all his eloquence to persuade the deluded people to give up their wicked design, but finding all he could say was disregarded by them, he ordered his domestics to take his bee-hives and throw them in the middle of the furious mob. This had the desired effect, and they were at once dispersed and put to flight,-happy, indeed, if they escaped witlout being stung.

In the spring of 1848 , two valued missionaries in India were attacked by bees, and had nearly lost their lives. They had gone on a little excursion, during 
the time of their vacation, with a few friends, and some pupils under their own care, for the purpose of inquiring into the natural history and antiquities of the country. While they were thus engaged, unexpectedly, and, so far as they knew, not laving provoked them at all (though these insects may have been previously angered in some way), they were assailed by an immense cloud of wild-bees. One of the missionaries was the first of the company attacked, and, after trying in vain to defend himself from injury, he sank upon the ground, where he lay almost totally insensible for nearly an hour, before he was found by his friends and relief afforded to him.

The other missionary, Dr Wilson, attempted to join his friend when he first gave the alarm, and himself at once came into contact with thousands of the enraged insects. He says, "I sprang into a bush for shelter; but there I got no covering from their onset. In my attempt to free myself from agony and entanglement, I slid over a precipice, tearing both my clothes and body by the thorns in the rapid descent of about forty feet. From the number of bees still about me, 
and my inability to move from them, I had a strong impression upon my mind, that unless God himself specially interposed in my behalf, all my wanderings and journeyings must then have terminated, though by the humblest agency, - that of the insects of the air.

"But God did save! I had kept my hold of a couple of square yards of blanket, with which I had gone to assist my friend, and this now seemed a providential succour, for with it my head was covered, and thus partly protected by it, I lay till the bees left me; when, frorn the poison of the numerous stings which I had received, violent sickness and other agitation came on, and my pulse failed, and my heart fainted. A native Indian, who had come up, pulled me into the shade, and made a noise which was heard by our friends, who had set out in search of me, and who otherwise would probably never have sought for me in the spot where I was lying. Among the friends was our physician, to whose treatment, under God, our recovery is in a great measure owing. We were conveyed to our tents, principally in native carts; and, 
on Saturday, we were brought to Bombay. Through the kindness of our heavenly Father, to whose grace we owe our great deliverance, we are both doing well, and hope in a few days to be free from the pain, if not the inconvenience, arising from this affliction."

The writer adds, "I have known instances of natives losing their lives by such an attack from the bees as we encountered, and the danger from which we have been delivered was great indeed. The wildbee of India is of a dark chocolate-colour, and about an inch and an eighth in length; and it is one of the same variety which $I$ have seen in the Holy Land. 'They compassed me about like bees,' is one of the appropriate figures of the Psalmist; and the illustration has now to us a depth of meaning which we had never before realised."

David is speaking of the attacks of the wicked, and he compares them to these fierce little creatures, and the manner in which they cluster upon the person who is the object of their displeasure, and we perceive how striking is the comparison. But he also declares his confidence in God, and that $\mathrm{He}$ will preserve him. 
"They compassed me about like bees;" but, "in the name of the Lord I will destroy them." So these servants of God escaped with their lives, when in so great danger from the wild-bees, for He helped them. "Thou hast thrust sore at me, that I might fall: but the Lord helped me. The Lord is my strength and sung, and is become my salvation." 


\section{CHAPTER XI.}

AGE-FLIGIT OF TIE BEE-BEE-IIUNTLR-TRANSPORTATION OF MIVES.

Trme honey-bees do not live very long, even when they are taken care of, and live peaceably all their days. The drones live but a few months; the workers less than a year; the queen longer than any of the bees; some think two years, but the exact length of her usual life has never been certainly known.

These little insects are not active in the winter; they sometimes appear to be almost in a torpid state, but if the weather becomes mild, and the sun shines warmly upon the hive, they soon arouse themselves and are quite lively. They are sometimes led, by the bright sunshine, to come out of their hives in mid-winter, and perhaps fly off into the air; and then the cold north wind chills their limbs, and they 
are not able to return to the hive, but perish in the fields.

It is quite remarkable that the little bee can find her home again at all times so readily when she has flown off in her search for food, often more than a mile or two miles distant. When, after having settled in a new location, they for the first time leave the hive on an excursion, they turn round, as if to observe the entrance, and then, wheeling off in a circle, fly far away. There, in all their wide pasture-grounds, busily employed in collecting their stores, they are never lost.

They have a dread of rain, and if a heavy cloud passes before the sun, they often return home in great haste. But when they continue their work till their load is completed, and take the direction in which their home lies, their course towards it is as direct as the flight of an arrow. Though their hives sometimes stand in gardens surrounded by shrubbery, yet, as they know the way, and return in great speed, taking the shortest route towards it, we must suppose that there are marks guiding them, which escape our notice. 
Each bee will fly directly to its own hive, though there may be many others near, resembling it in appearance. This well-known habit of the bee is very useful to those persons who, in America, search for the hives of the wild bee, and track her to hor home in the woods, to find her nest, and take away her honeycomb. In order to do this, the bee-hunter takes his stand some where upon the broad prairie, where the flowers of the white clover and other rich blossoms are opening in summer, provided with the few articles he needs to entrap the unthinking bees. A wooden plate is set down upon the ground, or on some snooth old stump, and upon it a small piece of comb, containing honcy. Then watching the bees closely, while thousands of them around him are busy at work, he selects one little insect while lodged in the cup of sone bright flower, or sipping from a head of white clover, and puts quickly over it a small glass tumbler, which he carries with him.

The little bee, thus disturbed, rises up in the glass, and finds itself a captive within it. The hunter, then placing the tumbler on the wooden plate, with the 
piece of honeycomb within its circle, and covering the glass, so that the light cannot enter it, the bee is soon attracted by the honey, and begins to feed upon this new treasure. When several bees have been caught and imprisoned in the same way, and have eaten their fill, one is suffered to depart, and first circling for an instant around, it rises swiftly in the air, and makes off, in a straight or bee-line, as it is called, to its home.

The hunter marks well the course it takes, with his practised eye or with his pocket-compass, and then moving to the distance of a few hundred yards from the spot, lets a second bee fly, and then again a third, all the time marking closely the direction of their flight. If the bees take entirely opposite directions, he supposes them to have come from different hives; but if the spot from which the first bee flew, was half a mile from that where the second rose into the air, and they belonged to the same live, each would at once take the course toward it, in its own bee-line. As they never cross each other's track, but go straight to their home, these bee-lines are sure to meet some where in 
the distance; and at the point where they meet, will be found the hive.

To track them on the line of their flight, so as to judge of this point, is the hunter's great care; and he rarely fails to find the spot, where, in some hollow, but not much decayed tree, these busy creatures have built their nest, and stored their sweets perhaps for years. To get at the honey the tree must be felled, and prostrated on the ground, and the poor insects lose every thing they possess, if, indeed, they escape with their lives. Hundreds of pounds of the most beautiful honeycomb have been found within the body of a single tree.

Even where the bee-hives are not stationary during the season of flowers, the instinct of the bee leads it always to find its home. In some countries it is a common custom with the people to remove their hives from one district to another, that the bees may make a larger collection of honey. In Lower Egypt, the flowers do not bloom so early by several weelss as in Upper Egypt, where the climate is milder. About the end of October the hives are collected together 
from the different villages, numbered, marked with the names of the owners, and placed in boats prepared for the purpose. The boatmen take charge of them, and they are conveyed slowly up and down the river Nile, stopping a few days at a time, at certain stages of the journey, where the pasture for the bees is most plenty, the hives remaining in the boats. In about three months, they are returned to the place from which they had been carried; the little bees having in this way visited the sweet orange-flowers of the country, the Arabian jessamine, and a variety of other blossoms, repaying their owners for their care of them with a quantity of delicious honey, and an abundant supply of beeswax.

In Persia, and in some parts of Asia Minor, the practice of transporting the bees from place to place, in search of food, is said to be common. In the spring, when the herbage of the low countries has become dry and parched, the owner of the hives closes them up tightly, and conveys them to some village in the neighbouring mountains, where sweet flowers are plenty, and hires some one to watch and take 
care of them till, in October, he removes them back to his home. These hives are usually made of straw, and therefore are light, and more easily transported in this way.

"Thou cheerful bee, come, freely come, And travel round my woodbine bower, Delight me with thy wandering hum, And rouse me from my musing hour. Oh, try no more yon tedious fields, Come, taste the sweets my garden yields; The treasure of each blooming mine, The bud, the blossom, all are thine.

"And careless of the noonticie heat, I'll follow as thy ramble guides, To watch thee pause to chafe thy feet, And sweep them o'er thy downy sides. Now in a flower-bell nestling lie, And there thy busiest labour ply; Then o'er the stem, though fair it grow, With touch rejected, glance and go.

"O nature kind! O labourer wise ! Thou roam'st along the summer ray, Glean'st every bliss thy life supplies, And meet'st, prepared, thy wintry day. 
110 THE HIVE AND ITS WONDERS.

Go, envied, go, with crowded gates, The hive thy rich return awaits; Bear home thy store in triumph gay, And shame each idler on thy way!" 


\section{CHAPTER XII.}

WAX-HONEX.

Tre wax which we obtain from the industrious little bee is an article of great value. It is the wax of which the bee forms her beautiful comb; of this the cells are built, where the honey and the bee-bread are stored, where the eggs are laid, and the young bees are nursed.

The combs, filled with honey, when taken from the hive, are first placed to drain, when the finest and purest honey runs from them. They are then closely pressed to obtain the remainder; after which, all the particles of the comb are collected for the salke of the wax. To prepare the wax for use, the combs are put into a woollen bag, and the bag placed in a kettle of water, over the fire. When the water has boiled for some time, the bag is taken out, and the water is set 
aside to cool; the wax then rises to the top of the water, when it becomes solid and is taken off in a cake. If this cake contains impurities, it is put into a clean bag, and again placed in boiling water, to make it quite pure; then melted and poured into cups or pans of any shape, where it hardens into cakes. It is usually brought to market in round, flat cakes, yellow in colour, and having a pleasant smell.

White wax is nothing more than the yellow wax bleached by exposure to the air, the heat of the sun, and moisture. The yellow wax is first melted, and then made to fall in streams over a roller, which, as it turns, is kept constantly wet in cold water. As the melted wax falls upon the roller, it cools and hardens into thin, ribbon-like shavings. These shavings are removed, and spread out upon linen cloths stretched on frames, in the sun; here they are frequently watered and turned, till they become white; when these thin shavings or flakes are melted again and cooled into small, round cakes of clean, white wax.

Beeswax is used for some purposes in medicine; 
and from it the finest candles are made. In parts of Europe, and in South America, great numbers of waxcandles are burned by the people in their religious ceremonies, and they consume many thousands of pounds every year in this manner.

You would scarcely have imagined that those slight and delicate combs, prepared with so much labour and care by so small an insect, would have yielded such an abundant supply for the wants of man. We, to whom the Creator has given intelligence so superior to that which this little creature possesses; we, who are gifted with reason, cannot equal the bee in her labours; we could never produce the wax to form the cells of her honeycomb! We can only think of these things with wonder, and try to feel humble as we ought.

The value of these little cells of wax, in the preservation of the honey, is very great. When the honey is taken from the comb and poured into jars, it soon ferments in warm weather, and spoils even when kept in a place much cooler than the bee-hive. Why, then, does the honey in the hive keep good? Because it is contained in these separate little cells, instead of 
being in one mass, as it must be in a jar. Each cell is entirely separate from the other cells; and each one, when full, is carefully closed from the air by a lid of wax. The quantity is so small in each that it never ferments. What, then, could the bee do with the honey, if it had not the wax, and had not been taught to build the cells? She could not store it up for winter, or keep it for any length of time. But she prepares the wax and builds the cells to contain the honey and to preserve it; and then collects the honey and stores it away in this remarkable manner.

Wax is a substance which very quickly softens and dissolves when heat is applied to it. An allusion to this property is evidently intended by the Psalmist, when describing, as in his own person, in the $22 \mathrm{~d}$ Psalm, the sufferings of the Messiah, he says, "My heart is like wax; it is melted in the midst of my bowels." Again, in proclaiming the majesty and glory of the Lord, in the 9\%th Psalm, he exclaims, "The hills melted like wax, at the presence of the Lord, at the presence of the Lord of the whole earth." The figure is a striking one, to point out how those 
who remain the enemies of the Lord shall be utterly destroyed and perish before him.

The prophet Micah makes use of the same illustration in his prophecy: "The mountains shall be molten under him, and the valleys shall be cleft as wax before the fire." In another Psalm also-the 68th-David breaks forth with the exclamation, "Let God arise, let his enemies be scattered: let them also that hate him flee before him. As wax melteth before the fire, so let the wicked perish at the presence of God."

Let us be careful that we are found not in the number of those who reject the mercy of God and the love of the Saviour, and so are driven away in our wickedness from his glorious presence. But let us rather seek with our whole hearts to partake of those blessings which David rejoices in, when he immediately after exclaims, "But let the righteous be glad; let them rejoice before God: yea, let them exceedingly rejoice."

But not only is the wax prepared by the little bee useful; the honey is also a most important article for the service of man. The busy bee provides not only 
enough for the wants of her own family, but she has a great deal to spare for others. When sugar was not so plenty and so cheap as it now is, honey was more highly thought of as an article of food, though it is still valued by many as a luxury.

In some of their offerings to their idols, amongst the ancient heathen, honey was made a part of the ceremony; and perhaps for this reason it was not allowed in any burnt offerings of the Jews, as they were always to be distinguished from the idolatrous nations about them by the difference in their manners and customs, and especially such as belonged to their religion.

The best honey is very light-coloured and transparent, and generally is collected early in the season, and the same honey is always purer and better when found in new comb. If it remains longer than a single season in the hive, it becomes dark in colour, and is much less valuable. In separating the honey from the comb, the finest is always that which drains or runs off of itself, from the purest and whitest combs ; the next is that which is simply pressed from the comb; 
and an inferior quality is obtained after this, by heating the fragments of comb, and again pressing them. Honey is always more rich and delicate, and has a finer flavour, while still in the comb, than it ever has after being separated from it by any process. Some allusion to this difference seems intended by King David, when, in the nineteenth Psalm, speaking of the law and the judgments of the Lord as contained in the Scriptures, he declares, "More to be desired are they than gold, yea, than much fine gold; sweeter also than honey, and the honeycomb." David seems here to compare the honey with gold while still mingled with the dross, and the fine or pure gold with the more delicious honey in the comb. The same distinction may be referred to by Solomon when recomniending the pursuit of wisdom in the Proverbs: "My son, eat thou honey, because it is good; and the honeycomb, which is sweet to thy taste."

To teach us the well-known lesson that hunger sweetens the most common repast, we are also told by the same sacred writer, "The full soul loatheth an honeycomb; but to the hungry soul every bitter thing 
is sweet." How often do persons complain of their food, and find fault with it, only because they have no healthful appetite, and perhaps have been spoiled with dainties! 


\section{CHAPTER XIII.}

INSTINCT OF THE BEE.

How has the little bee obtained the knowledge she possesses? She has not gained it by experience. She has not tried, first one plan, and then another, for her curious works, and then decided upon that which, on the whole, she thought to be best. This could not be. She was not taught these skilful arts by other bees, older and wiser than herself. No: each little bee as well understood, at the beginning of her life, how to perform her allotted task, as she did at the close. She is provided with the instruments ready for her work, and she uses them properly. She begins the work of her life in the right way; and in the same way she carries it on, with the most perfect order and system, till, in a few short months, it is all ended.

The wondrous faculty which this insect enjoys, to 
direct all its proceedings, is called instinct. It is given to her, and to other insects and inferior creatures, by the Creator of the world. This gift is all the teaching which they need. It is their guide in all things, and keeps them from mistake.

Thus the bee is taught to prepare the wax, to build her cells, to collect the honey, and to store it away. Thus she is taught to arrange the different cells, where the queen-bee is to lay eggs, to protuce the workers, the drones, and the royal young. Thus the queen herself knows where to place the eggs; and the nursebees how to take care of them, and at the proper time to give nourishment to the little ones as they are hatched. The bees are thus taught to divide their labours; the wax-makers, the nurses, and the honeygatherers, each attending to their own work. Without gaining that skill from practice which is called experience, and without instruction from other bees, or imitating them, the little creature goes on to do always what is best for itself, best for the family or society of bees in which it lives, and best for man, who is to enjoy much of the fruit of its labours. It goes on 
uniformly too, and builds in the same way now that bees built thousands of years ago.

All classes of animals have instinct, which teaches them many things necessary for them to know, to preserve their lives, to provide for their young, and to defend them; but none of them appear so well furnished, with instincts so various, so refined and perfect, as the insect races. No wild beast of prey, no bird, nor fish, can weare a net to catch its enemies or friends, and keep them for its food, so cunningly as can the little spider! And what larger animals can be thought of, who, living together in one society, build cities for themselves, with streets and dwellings in regular order, and warehouses for provisions, and there lay up a store sufficient for the wants of all the inhabitants of the city in a future season? Which of them can be compared with our wise little insect, the bee, who does all this, and much more? The crafty spider, with its web, has indeed singular wisdom and skill, but it can never be thought to equal the wonderworking bee!

The bees not only do those things right which 
are always to be done in the same way, but it is even more remarkable, that, when their wauts require it, they alter their arrangements accordingly. The cells where the eggs are laid and the young ones hatched are closely covered by the bees; but as the little grub wraps itself in a shroud of silken tapestry, which itself weaves, it must have room within the cell for all its movements while doing this. On one occasion, a swarm was placed in a very flat glass hive, and the bees built a comb along one of the sides where there was not room to make all the cells of their usual depth. Here they would seem to have made a mistake.

The queen, however, laid her eggs in them, the young ones were fed at the proper time, and the cells closed over as usual. But in a few days holes were seen in the lids, and the young ones came partly out, because they had not room. What did the bees do? They did not pull out the grubs and let them die, as they sometimes do, when there is disorder in the combs. They did not displace a single one of them. Their instinct taught them what was best, and they closed the cells again with fresh lids, much more convex (or 
raised in the centre) than before, so as to give sufficient room to those within. No more holes were made in the lids from that time.

In building the comb, the bees fasten it to the top of the hive, as you bave read, by making the upper row of cells with one broader side, and cementing this fast to the roof. 'This is quite a sufficient support for a time; but, as the combs are filled with honey, and contain a store of several pounds, they seem to foresee the danger of so great a weight becoming too heavy for the waxen walls to bear. Now, what do the little creatures do? They go at once to work to gnaw away the sides of these upper cells, and, mixing the wax with propolis, they compose a very firm cement, and with this they form thick solid walls between the comb and the top of the hive, so as to fasten them securely together. At this they work, first on one side of the comb, and then on the other, making fast the cells as they proceed with the new cement, and taking care not to loosen too much at once, or the whole might fall down together.

How singular and how varied are the instincts 
which the Creator has given to this weak, frail, and short-lived little insect!

A gentleman, quite celebrated as a keeper of bees in this country, relates the following circumstance as occurring under his own observation. An entrance or opening to one of his hives, about two inches long and half an inch broad, was covered by a thin slip of wood, with a nail at one end to hold it fast. The bees had no particular need of this entrance, as they had another door; but to give them air, as the weather was warm, if he found it closed, he turned up the slip of wood. At last, it became quite loose from moving it so often, and would fall down of itself.

Not thinking it important to secure it at once, every day as he passed by he lifted it up, and the next day found it down again. This he did for a week, and one morning, lifting it up as usual, out rushed perhaps a hundred bees, and began to cluster around it in a very singular manner. He left them, and did not return to the hive till the next morning, when he found the loose slip of wood so deeply imbedded in a cement of propolis, that it could not be easily removed. 
It seemed from this that the bees wished the hole open, or that the moving of the slip up and down had annoyed them, and they resolved to put a stop to it at once, and this they did quite effectually.

We can only say of these ingenious insects, that God has made them so. It is pleasant to think of his goodness, as it is shown to us in the wonders of the inferior creation. Should we make these wonders the study of every day, the longest life would be too short for us to discover and dwell upon them all.

But if the love of God has done so much for the smallest and meanest of his creatures, how much more has it done for us, to whom are given high powers of thought and reason! He has made us capable, not only of perceiving that there is a God, the Creator and Ruler of all, but of understanding much of the perfection of his character.

He has revealed that character to us, and taught us all his will respecting us in the sacred Scriptures; and there he commands us to learn his will, and to submit ourselves to him, as dear and obedient children.

But God hath loved us with a love so vast, so 
infinite, that he spared not his only begotten Son, but gave him up for us all. We are rebellious children, and Jesus hath so loved us as to die for us. "Greater love hath no man than this, that a man lay down his life for his friends ;" but Jesus Christ our Saviour hath died for us when we were enemies, that, being enemies, we may be reconciled to God by the blood of his cross.

May it be our delight to study, not only his works, but his blessed Word, and may our hearts be drawn by, his Holy Spirit to love him, to put our trust in him, and to do his holy will! This is his will concerning us, "That we should believe on the name of his Son Jesus Christ, and love one another, as he gave us commandment."

"Who, in the music of birds and bees, In the liquid sound of the summer breeze, Wafting the sweet-scented violet's breath, Dreams of the hour of decay and death?

"Say, shall we darken a scene so fair?

Yes, death and decay find an entrance there;

But those shades fall not in realms above: They are ever light with the Father's lore. 
"They are cheered by the songs of the saved and blest; The weary and faint ones are there at rest:

Not a cloud shall pass o'er their peacerul sky, In the land where they weep not, nor sin, nor die."

TUE END.

ZUINBURGH: PRINTED BY JOHASTUNE AND HUNTER. 
-

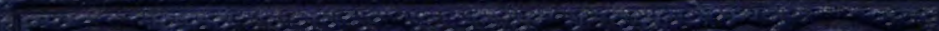

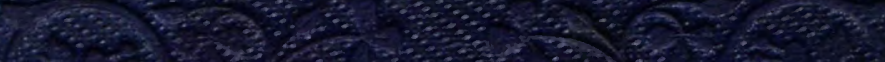
2.

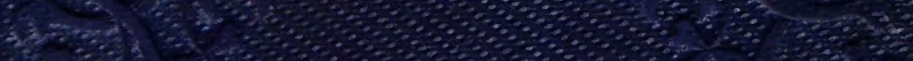

The

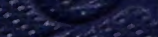

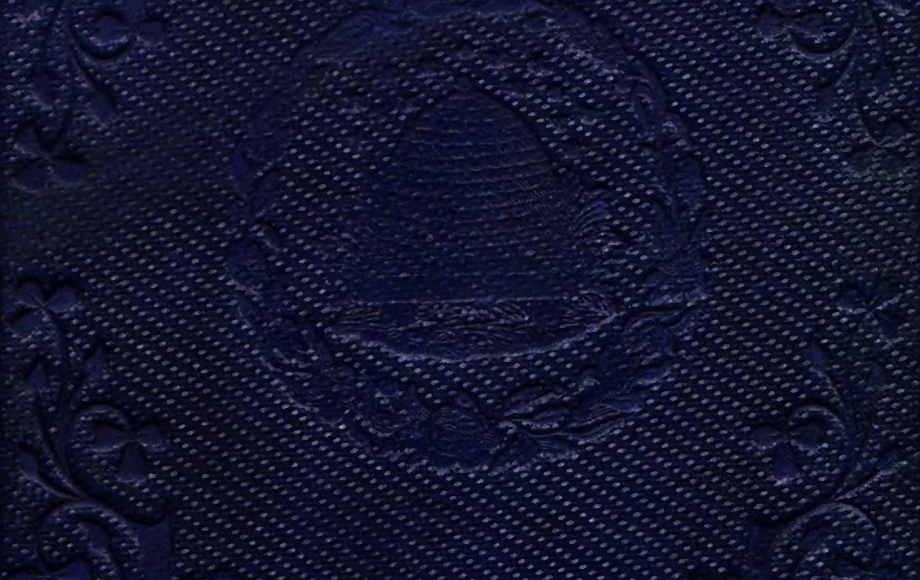

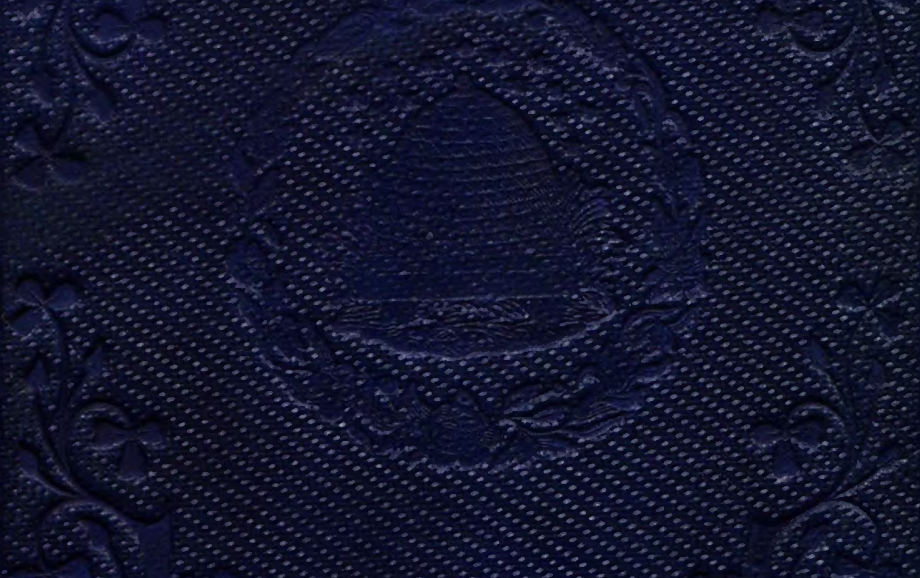

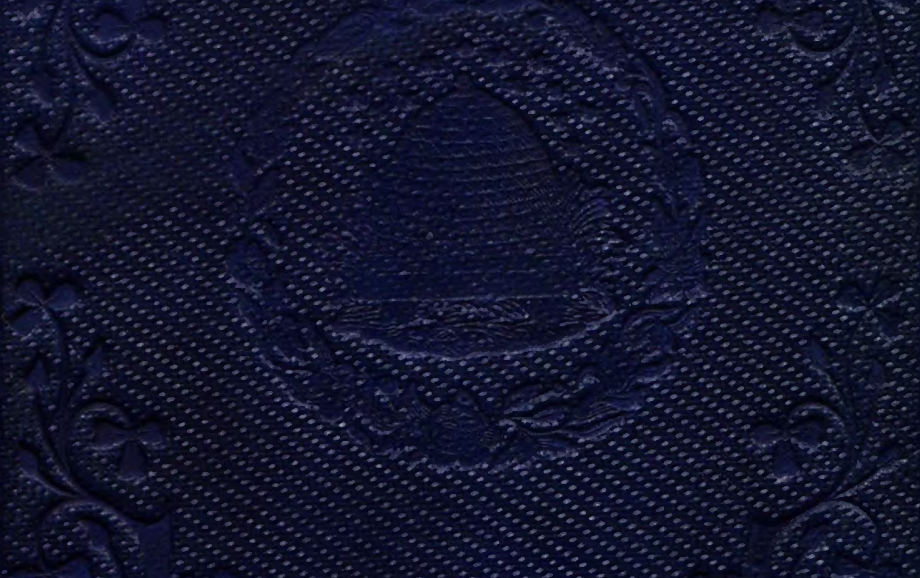

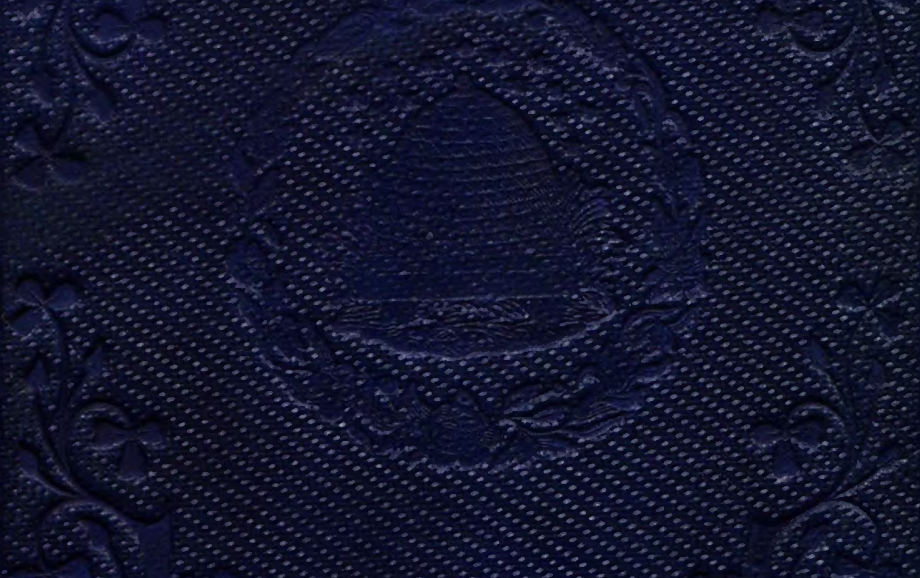

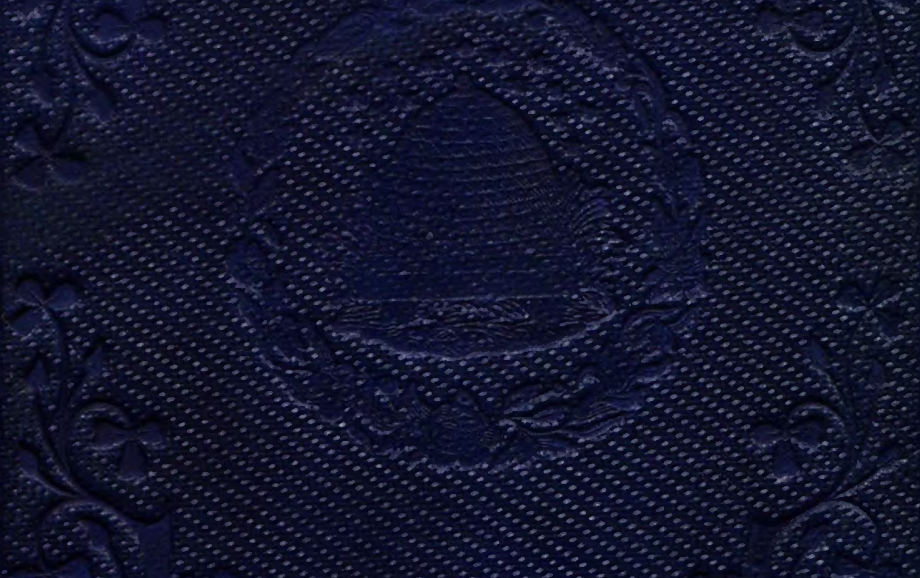

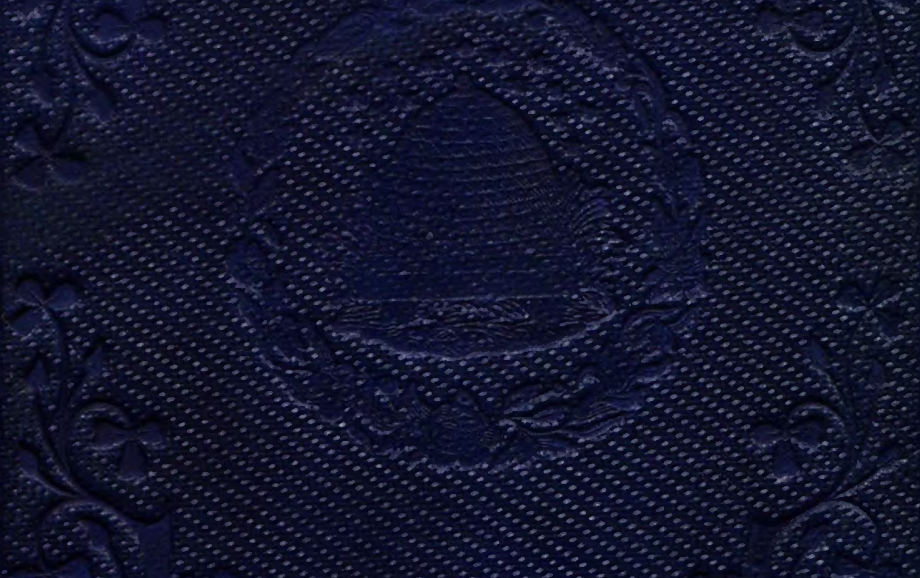

$$
=0
$$

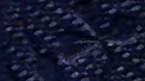

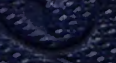

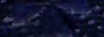

5.s.

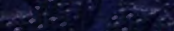

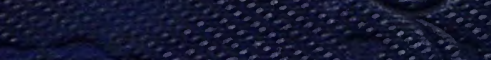

